\title{
United STATES CURRENT ACCOUNT DEFICITS: A STOCHASTIC OPTIMAL CONTROL ANALYSIS
}

\author{
JEROME L. STEIN \\ CESIFO WORKING PAPER NO. 1805 \\ CATEgORy 6: MONETARy Policy and InTERnATIONAL FinanCE \\ SEPTEMBER 2006
}

An electronic version of the paper may be downloaded

- from the SSRN website:

- from the RePEc website:

- from the CESifo website:

www.SSRN.com

www.RePEc.org

www.CESifo-group.de 


\title{
United STATES CURRENT ACCOUNT DEFicits: A STOCHASTIC OPTIMAL CONTROL ANALYSIS
}

\begin{abstract}
The "Pessimists" and the "Optimists" disagree whether the US external deficits and the associated buildup of US net foreign liabilities are problems that require urgent attention. A warning signal should be that the debt ratio deviates significantly from the optimal ratio. The optimal debt ratio or debt burden should take into account the vulnerability of consumption to shocks from the productivity of capital, the interest rate and exchange rate. The optimal debt ratio is derived from inter-temporal optimization using Dynamic Programming, because the shocks are unpredictable, and it is essential to have a feedback control mechanism. The optimal ratio depends upon the risk adjusted net return and risk aversion both at home and abroad. On the basis of alternative estimates, we conclude that the Pessimists' fears are justified on the basis of trends. The trend of the actual debt ratio is higher than that of the optimal ratio. The Optimists are correct that the current debt ratio is not a menace, because the current level of the debt ratio is not above the corresponding level of the optimum ratio.
\end{abstract}

JEL Code: C61, F32, F34, F37.

Keywords: U.S. current account deficits, external debt, stochastic optimal control, dynamic programming, inter-temporal optimization.

Jerome L. Stein

Division of Applied Mathematics

Box $F$

Brown University

Providence RI 02912

USA

Jerome_Stein@Brown.edu

I am deeply grateful to Peter Clark for his insightful criticisms of a previous draft and suggestions for revision. 


\section{Pessimists and Optimists}

For nearly a quarter of a century, the US has persistently run significant current account deficits. The cumulative consequence of these deficits is that the US has been transformed from the world's largest net creditor to its largest debtor. The current account can be viewed in several ways. It is net foreign investment, equal to national saving less investment. A positive (negative) current account is equal to a capital outflow (inflow). National saving is the sum of private saving of firms and households plus government saving (the budget surplus). Figure 1 graphs the current account/GDP of the United States, equal to net foreign investment/GDP and labeled NETFIGDP. The sample period is 1977q1 - 2004q2. Paradoxically, during the period 1996-2004 capital inflows to the US have been associated with capital outflows from Japan and the "developing countries"1.

The current account is defined as the sum of the trade balance of goods and services plus net investment income from US assets held abroad less foreign assets invested in the US. The trade balance/GDP is graphed in figure 1 as BOPBGSGDP. Figure 1 shows that the current account is almost entirely dominated by the trade balance ${ }^{2}$. The trade balance has been in deficit over the sample period, and has widened steadily and significantly. Thereby the US became a debtor country. However, the balance on investment income is a negligible fraction of the current account, despite the growth in the external debt. At present, there is no evidence of an external debt burden.

\footnotetext{
${ }^{1}$ Bernanke (2005, table 1 ).

${ }^{2}$ The data used in this paper come from the Federal Reserve Bank of St. Louis FRED.
} 
Figure 1. Balance of payments goods and services/GDP (BOPBGSGDP) and current account/GDP = NETFIGDP $=$ net foreign investment/GDP 1977q1-2004q2.

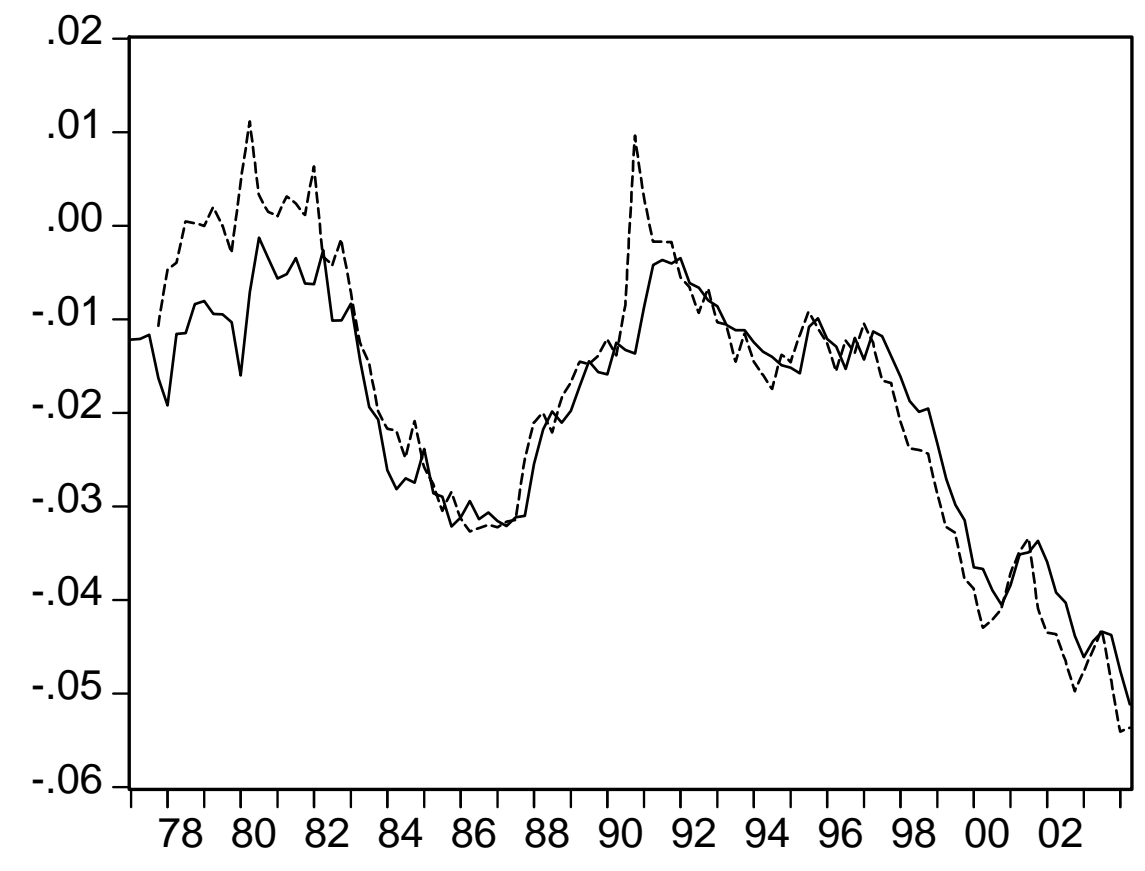

BOPBGSGDP ----- NETFIGDP

Figure 1. Balance of goods and services/GDP = BOPGSGDP; Current account/GDP = Net foreign investment/GDP = NETFIGDP; sample period is 1977q1 2004q2. The balance of investment income/GDP is the difference between the two curves. The data are from Federal Reserve Bank of Saint Louis, FRED.

The situation graphed in figure 1 has led Ben Bernanke ${ }^{3}$ to pose several questions. (B1) Why has capital rich US been borrowing heavily, rather than lending on the international capital markets, from the capital poorer countries? (B2) What implications do the US current account deficits and associated debt have for the performance of the US and world economies? (B3) From a global perspective, are these developments economically beneficial or harmful in the long run as well as in the shorter run? Based upon the answers to these questions, what are theoretically based Early Warning Signals of an impending crisis?

\footnotetext{
${ }^{3}$ Bernanke, op. cit.
} 
In view of the level and trend of the current account and trade deficits in figure 1, the apprehensions have been repeated and reemphasized by many economists. Refer to them as the Pessimists. At one extreme is the group that claims that the continued current account deficits and growth of the debt portend a collapse of the dollar. They do not clearly specify if the menace is the current account deficit/GDP or the debt/GDP ratio, and have not provided any early warning signals that involve both a number and a date. Figure 2 graphs the US current account/GDP, as a four-quarter moving average to smooth the data, alongside the real trade adjusted value of the US dollar REALTWD, relative to the major currencies. Both variables are normalized for comparison. A rise is an appreciation of the dollar. The deficit has been large and growing since 1991. By the fourth quarter of 2004, the deficit was 6.2 per cent of GDP. There has been no downward trend in the real value of the US dollar, and certainly no collapse despite the growing current account and trade deficits since 1991. The predictions of the extreme pessimists were not based upon a consistent and empirically verified theory. 
Figure 2. Real trade weighted value of dollar against major currencies. REALTWD. NETFIGDPMA Net foreign investment/GDP, four quarter moving average. A rise is an appreciation of the US dollar.

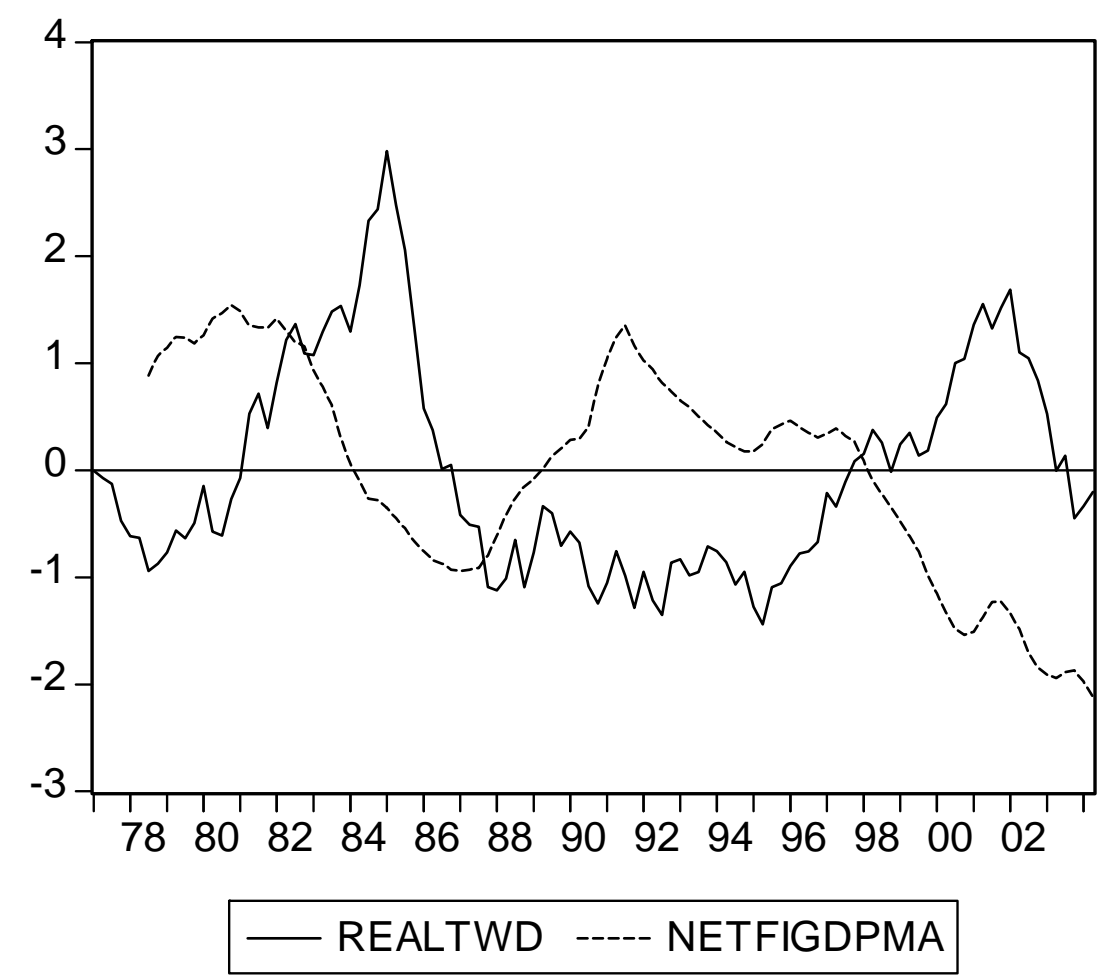

Figure 2. United States current account/GDP = net foreign investment/GDP = NETFIGDPMA, four quarter moving average (MA) and the real value of dollar against the major currencies $=$ price adjusted major currencies dollar index $=$ REALTWD. A rise is an appreciation of the US dollar. Normalized variable $=($ variable - mean $) /$ standard deviation. Period:1977q1 - 2004q2. Source: Federal Reserve, Washington DC and Federal Reserve Bank of St. Louis, FRED data bank.

The main group of the pessimists, such as Michael Mussa (2004), relies upon a quite simple argument. If the current account deficit/GDP is constant at $A$ and the ratio of external debt/GDP stabilizes at $h$, then the ratio of the current account deficit/debt is equal to $g$, the growth rate ${ }^{4}$. That is, the equilibrium debt ratio $h$ is equal to current account deficit/GDP divided by the growth rate, equation (1).

(1) $h=A / g$

\footnotetext{
${ }^{4}$ This relation abstracts from the capital gains and losses resulting from changes in the exchange rate.
} 
This equation is valid for any constant current account deficit/GDP and positive growth rate ${ }^{5}$. It does not tell us what debt ratio is sustainable or answer Bernanke's question (B3) above. The reason is the following. If the current account deficit/GDP rises to a multiple of A then the equilibrium debt ratio will rise to a multiple of h. Which of the infinitely stable debt ratios should set off early warning signals? ${ }^{6}$

Mussa and others consider several scenarios, involving a 5\% per annum growth rate. If the deficit $\mathrm{A}=5 \%$ then the debt ratio $\mathrm{h}$ will converge to $100 \%$. If the deficit is reduced to $4 \%$ then the debt ratio converges to $80 \%$. Mussa concludes that no one knows, or can estimate with great confidence, the outer limits of the US net foreign liabilities that are sustainable in the sense that they would be tolerable to both US residents as net debtors and to the rest of the world residents as creditors. All that he can say is that since no country of significance has ever run up an external debt ratio of $100 \%$, it is prudent to conclude that this boundary should not be tested. The conclusion is that this group of pessimists relies upon panel data of countries over time to form a subjective estimate of an early warning signal for the United States. They do not provide a theoretical framework to answer questions (B3) and (B4) above.

The current apprehensions of the main group of Pessimists - Mussa, Edwin Truman, and John Williamson - may represent the consensus feeling ${ }^{7}$, but are not shared by all economists. There is a group of Optimists, represented by Ben Bernanke and Richard Cooper. The differences between the two main groups are subtle but significant.

One can simply describe the Optimists' view via equation (2). The current account deficit of the US (country 1 ) equals US investment less saving, where I = investment/GDP, $\mathrm{S}=$ saving/GDP and $\mathrm{Y}=\mathrm{GDP}$. Investment less saving is a demand for resources from the rest of the world. US current account deficits are financed by foreign

\footnotetext{
${ }^{5}$ Let the current account deficit/GDP be A(t), which is not necessarily constant, and let the growth rate of GDP be constant at $g>0$. The dynamics of the debt ratio are: $d h(t) / d t=A(t)-g h(t)$. The solution is: $h(t)=$ $\mathrm{h}(0) \exp (-\mathrm{gt})+\int \mathrm{A}(\mathrm{s}) \exp (-\mathrm{g}(\mathrm{t}-\mathrm{s})) \mathrm{ds}$, where $\mathrm{t}>\mathrm{s}>0$. If $\mathrm{A}(\mathrm{t})=\mathrm{A}$ constant, then equation $(1)$ is derived as $\mathrm{t}$ goes to infinity.

${ }^{6}$ Some economists call the Intertemporal Budget Constraint a situation where the debt ratio stabilizes at a finite level. The above argument explains why an infinite number of current account deficits and debt ratios are consistent with dynamic stability.

${ }^{7}$ See the articles in Bergsten and Williamson, ed. (2004) and in Policy Briefs in International Economics (2005).Both are publications of the Institute for International Economics.
} 
current account surpluses, which are saving less investment $\left(S_{2}-I_{2}\right) Y_{2}$ - the supply of resources - from the rest of the world (country 2).

(2)US current account deficit $=\left(I_{1}-S_{1}\right) Y_{1}(t)=\left(S_{2}-I_{2}\right) Y_{2}(t)=$ Foreign current account surplus.

The Optimists claim that the US investment ratio $I_{1}$ tends to be high because the US offers more productive investment opportunities than do Japan and Europe. The saving ratios are higher abroad $\left(\mathrm{S}_{2}>\mathrm{S}_{1}\right)$ than in the US. Hence optimizing behavior by both leads to US current account deficits and foreign current account surpluses. Both countries benefit from the flow of resources from the rest of the world to the US. Insofar as $\left(I_{1}-S_{1}\right)$ is positive and $\left(I_{2}-S_{2}\right)$ is negative, as long as GDP is growing in both countries, there is no problem. Continued US current account deficits are not causes for alarm, because foreigners are induced to absorb ever-growing quantities of US debt into their portfolios.

Bernanke is explicit that one must take a global point of view in order to answer his questions. An important factor driving US current account deficits has been the substantial shift in the current accounts of developing countries. These shifts, together with the high saving propensities of Germany and Japan, have resulted in a global saving glut. The increased supply of saving raised US equity values during the stock market boom and helped increase US home values. As a consequence US saving declined and contributed to the US current account deficit. He argues that this flow of resources has been desirable in the medium run, but in the longer term this pattern of flows could be counterproductive. However, there is no explicit theoretical analysis linking the medium to the longer run.

Cooper's analysis (2005, pp. 5-6) can be summarized within the framework of equation (2) above, and leads into our subsequent mathematical analysis. The current account deficit of the United States is likely to continue for many years because it has been beneficial to both borrower and lender. The excess saving in the rest of the world has been invested in the US where the rate of return has been higher. The danger is not in the deficit per se, but that the deficit will finance consumption or investment with a lower rate of return than the interest rate paid on the debt. 
The implied error made by the "Pessimists " is that they assume that there is an intertemporal budget constraint (IBC) " that the debt must eventually be paid off" ${ }^{8}$. That is not the case, because there is a steady growth in the debt demanded by the rest of the world. Both sides of equation (2) are positive and growing. Foreign excess savings seek the more productive investment opportunities in the US. That is why the Optimists believe that there is no rational reason for alarm in the medium run.

Catherine Mann's book, which represents the state of the art, contains a comprehensive and perceptive discussion of the issues and unresolved problems. She poses the problem as follows. Whenever a country's current account deficit grows large, questions arise as to how large it can get, how long it can persist, and what forces might either stabilize it or cause it to shrink. The history of financial crises in Latin America and Asia, shows that too much external borrowing and/or accumulated international obligations can precipitate financial crises and subsequently economic disasters. But what is it that precipitates the crisis? Is it the size of the deficit or the accumulated obligations? Do their particular characteristics - such as maturity or currency or their use for consumption or real estate ventures - contribute to the economic forces that precipitate a crisis?

To answer the question as whether the US current account deficit and net international investment position are sustainable one must define "sustainable" from two related perspectives: that of the net borrower (US) and that of the net investor (rest of the world). Experiences of different debtor countries with large current account deficits and net international obligations can help uncover empirical evidence of what constitutes sustainability. But will these be applicable to the US, or do different rules apply to the US because of the international role of the US dollar? The US is different from the rest of the world because of the depth and breadth of its financial markets and because it both borrows and lends principally in its own currency.

First, Mann looks at the borrower's constraint. A negative net international investment position (NIIP) cannot increase without bounds, since ultimately net investment payments on the negative investment position would use all the resources of

\footnotetext{
${ }^{8}$ The IBC has been used in many ways. (i) The debt stabilizes according to equation (1) above. (ii) The debt is ultimately paid off. (iii) The present value of the debt goes to zero. We explain below why none of these views is particularly helpful in answering Bernanke's questions (B3)-(B4) above.
} 
the economy, leaving nothing for domestic consumption. For the domestic economy, the importance of the stock of foreign claims is measured as NIIP/GDP. The growth rate of the economy affects the denominator and the interest rate on debt obligations in the NIIP affects the numerator. She states that the higher the share of share of equity obligations (which have a contractual service requirement less strict than bank debt), the longer a country can run current account deficits - since the investment service likely is lower. In addition, the higher the share of obligations in the domestic currency, the less vulnerable the country is to exchange rate volatility. She states that a country that borrows in its own currency at low interest rates and with a high share of equity can continue along a trajectory of spending and saving for longer than could a country that borrows in currencies other than its own, at high interest rates, and using fixed maturity debt.

Second, she considers the portfolio constraints of the investors. How much lenders are willing to lend to residents of a country is a function of the risk-return profile of the borrower's assets relative to other assets as well as the investor's attitude toward risk and desire to diversify investments. The growth of the investor's home economy, the size of the global portfolio and the size of alternative investments are important determinants of how much of a country's assets the foreign investor wants. If the variability of the rate of return on a foreign investment increases - because of variability either in interest rates or exchange rates - investment in that foreign asset generally declines.

\section{The Rationale of Using Stochastic Optimal Control and Dynamic Programming ${ }^{9}$}

The reality is a world where there is uncertainty concerning the GDP, interest rate and exchange rate. The technique of analysis used in this paper is based upon Stochastic Optimal Control/Dynamic Programming SOC/DP. It is the appropriate technique to use in inter-temporal optimization in a world of uncertainty. It provides a theoretical framework that contains Mann's analysis, can be implemented empirically, permits one to answer Bernanke's questions, and evaluate the arguments of the Pessimists and the Optimists.

\footnotetext{
${ }^{9}$ Stein (2006, chapter 9) contains a technical analysis of the issues discussed in this paper. Our aim here is to present the material in a manner that is accessible to economists who have an interest in this subject, especially from a policy perspective. Therefore I stress the method of analysis and conclusions, use a minimum of equations and refer the reader to the above reference for proofs.
} 
The object is to select ratios of external debt/net worth, capital/net worth and consumption/net worth in a world of uncertainty that maximize a performance criterion, subject to the constraints of both the borrower and lender. Consumption will be vulnerable to external shocks as a continuous function of the difference between the actual debt ratio and the derived optimal ratio. At each step we relate the mathematical approach to the arguments of the Optimists and Pessimists.

\subsection{Debtor and Creditor Constraints}

Catherine Mann explicitly and Richard Cooper implicitly stressed that an "unduly large" external debt is a menace if it would endanger the level and the growth of per capita consumption. The emphasis is upon the stock of debt not the current account deficit, which is its rate of change. The inter-temporal pattern of consumption subject to constraints must be a focal point of the analysis of what is an optimal or a sustainable debt.

A debtor constraint must be that, in the attempt to service the debt, the level of consumption must not be allowed to fall "too low". If the debt burden - defined as the service of the external debt/GDP - is "too high", there are several possibilities. One is that the debt would be "defaulted", in the sense that the terms of the contract would not be fulfilled. Second, if the creditors correctly anticipate such a situation, there would be a capital outflow, and a financial crisis would be precipitated. The constraints to the debtor can be understood from equation (3.1), the consumption of the debtor country - which is the United States.

The US has claims on foreigners and foreigners have claims on the US. For simplicity we just focus upon the net debt and not upon the components. The US has a net external debt $L_{t}$ where $\mathrm{L}_{t}$ is the debt denominated in US dollars. The real interest rate at which the debt is serviced is $i_{t}$. A negative debt is net foreign assets.

Stochastic variables are written in bold letters. Consumption $C_{t}$ is equal to the Gross Domestic Product $Y_{t}$ less investment $I_{t}$ less the servicing of the debt $i_{t} L_{t}$. The capital inflow is $d L_{t}$, the change in the debt at the current exchange rate. It is equal absorption less the Gross National Product. A negative capital inflow is an outflow.

(3.1) $C_{t} d t=\left(\boldsymbol{Y}_{t}-I_{t}-\boldsymbol{i}_{t} L_{t}\right) d t+d L_{t}>(C d t)_{\min }>0$. 
$\mathrm{Y}=\mathrm{GDP}, \mathrm{C}=$ consumption, $\mathrm{I}=$ investment, $\mathrm{L}_{\mathrm{t}}=$ external debt denominated in \$US, $\mathrm{i}$ $=$ real interest rate; Stochastic Variables $\Omega_{\mathrm{t}}=\left(\mathrm{Y}_{\mathrm{t}}, \mathrm{i}_{\mathrm{t}}\right)$

It is impossible to know what will be the future GDP and the real interest rate: stochastic variables vector $\Omega_{t}$. A popular concept in the economics literature is the Intertemporal Budget Constraint (IBC). This concept asserts that the paths of consumption and investment selected must be such that the expectation of the present value of the debt is zero. This concept is irrelevant in a stochastic system, for the following reason. Even if there were a plan that specified future values of consumption and investment, it is impossible to know what will be the future debt. To see this, sum up the terms $d_{t}$ from an initial date $\mathrm{t}=0$ to a future date $\mathrm{T}$ to derive equation (3.2). Then the U.S. debt at later date $\mathrm{T}>\mathrm{t}$ is (3.2) where the initial debt is $\mathrm{L}(0)$. The integrand is the current account deficit.

$$
\text { (3.2) } L_{T}=\int_{o}^{T}\left(C_{t}+I_{t}+\boldsymbol{i}_{t} L_{t}-\boldsymbol{Y}_{t}\right) d t+L(0)
$$

Since vector $\Omega_{\mathbf{t}}=\left(\mathbf{Y}_{\mathbf{t}}, \boldsymbol{i}_{\mathbf{t}}\right)$ is stochastic over the time horizon $(0, T)$, it is impossible to predict terminal debt $\mathrm{L}_{\mathrm{T}}$ - even knowing the paths of consumption and investment. Consequently it makes no operational sense to state that the maximization process is based upon the IBC - that expected present value of the terminal debt should be either zero or any other quantity. Such a "constraint" is unknowable and unenforceable.

It is likely that Mussa's pessimistic views are based upon the concept of the IBC, whereas Cooper and Bernanke do not rely upon the IBC. Instead of the IBC, in the stochastic optimization process there are constraints. One debtor constraint is that consumption must always be positive, $C_{t}>0$, regardless of $\Omega_{t}$ the state of nature. A second debtor constraint is that there be "no free lunch". Consider each in turn. Then we turn to the creditor constraints.

It is quite likely that there are shocks/ vector $\Omega_{\mathrm{t}}$ that reduce drastically the GNP = $\mathrm{Y}$ - iL in equation (3.1). In that case, consumption would have to be reduced drastically if the debt is to be serviced. Can these shocks always be compensated for by new borrowing, a capital inflow $\mathrm{dL}_{\mathrm{t}}>0$, and maintain the level of consumption? A second debtor constraint must be imposed to prevent a "free lunch" or "Ponzi Scheme". In a Ponzi Scheme or "free lunch" new borrowing is incurred to service the debt, so that 
absorption can continue to exceed GDP. We exclude the "free lunch" possibility by introducing a variable called net worth $\mathrm{X}_{t}$ equal to capital $\mathrm{K}_{\mathrm{t}}$ less debt $\mathrm{L}_{\mathrm{t}}$, equation (4), which we constrain to be positive. Bankruptcy is a situation where net worth is zero or negative.

(4) $X_{t}=K_{t}-L_{t}>0$.

The second debtor constraint - equation (4) - avoids the "free lunch" or bankruptcy problem in the following way. If new borrowing is incurred to finance the debt payments or consumption, the debt of the economy $\mathrm{L}_{t}$ grows steadily, but capital $\mathrm{K}_{\mathrm{t}}$ does not. This means that net worth is driven down to zero and continues to become negative. By constraining net worth to be positive, we preclude the "free lunch" problem. Moreover if it is clear that the country is heading towards bankruptcy, there will be a capital flight $\mathrm{dL}_{\mathrm{t}}$ $<0$ in equation (3.1). Then consumption will be driven down to an intolerable level, even before the negative shocks occur.

The debt $L_{T}$ in equation (3.2) can result from either private or public consumption or from investment. The big difference is that if it results from consumption, net worth declines. If this continues, net worth will be driven down to zero and violate the "no free lunch" constraint. If it results from productive investment, then capital will also grow, and net worth will not be driven down to zero. We shall see in the mathematical analysis below what are the determinants of optimal capital and investment.

There is also a creditor constraint. The US has both foreign assets denominated in foreign currency and liabilities to foreigners. Since the US debt is generally denominated in US dollars, it would seem that there is no exchange risk to the debtor country, the US. This is wishful thinking, because there is an exchange risk to at least one of the countries. Either the exchange risk is faced by the debtor or by the creditor country. A negative debt is a creditor position. Each one selects the optimal debt or net foreign assets by taking the relevant risks and returns into account. The debtor may disregard exchange risk, because the debt is denominated in his own currency. However, creditor must consider the risk in order to be induced to hold the risky debt supplied. Creditors will only do it if the debt supplied and interest rate charged take into account the exchange risk. The creditor constraint is that the US debt supplied be equal to the optimum net foreign assets demanded. 
We state this constraint formally as Market clearing equation (5). Denote the ratio of the optimal debt/net worth of country $\mathrm{j}=1,2$ by $\mathrm{f}_{\mathrm{j}}(\mathrm{t})$, and net worth by $\mathrm{X}_{\mathrm{j}}(\mathrm{t})$. A debtor has a positive, and a creditor has a negative, $\mathrm{f}(\mathrm{t})$. The excess supply of US debt must be zero. The optimal US debt supplied $\mathrm{f}_{1} \mathrm{X}_{1}$ is equal to the optimal debt demanded by the rest of the world.

(5) $f_{1}(t) X_{1}(t)+f_{2}(t) X_{2}(t)=0$.

The next step derives the optimal debt ratios $f_{j}(t)$ for each country, subject to the constraints $C>0, X>0$ and market balance equation (5). The inter-temporal optimization in the SOC/DP approach is based upon a criterion function and the stochastic processes for the GDP, real interest rates and exchange rates, to be discussed below.

\subsection{A Stochastic Optimal Control/Dynamic Programming (SOC/DP) Model ${ }^{10}$}

The controversy between the Pessimists and the Optimists cannot be resolved without a consistent, theoretically founded, and empirically operational framework. The Stochastic Optimal Control/Dynamic Programming SOC/DP analysis derives the optimal inter-temporal path of the utility of consumption, when there is uncertainty concerning the GDP, interest rate and also the exchange rate for the country that bears the exchange risk, vector $\Omega_{\mathrm{t}}$.

The "no bankruptcy" constraint equation (4) can be written as:1 = k - f, where $\mathrm{k}=$ $\mathrm{K} / \mathrm{X}$ is the ratio of capital/net worth and $\mathrm{f}=\mathrm{L} / \mathrm{X}$ is the ratio of the external debt/net worth. Given the net worth, there is a 1-1 correspondence between the capital/net worth and debt/net worth ratios. The object is to select (i) an external debt (or a net foreign asset) ratio, or a capital/net worth ratio, and (ii) a consumption/net worth ratio that maximize a performance criterion, subject to the constraints of both the borrower and lender, given the stochastic processes. The "controls"/policy instruments must be selected given available information. Since the future - vector $\Omega_{t}$ - is unpredictable, decisions must be made based upon available information - the current state of the system. This is the raison d'être of the SOC/DP approach.

\footnotetext{
${ }^{10}$ Technical details concerning the mathematics and use of stochastic optimal control/ dynamic programming are in: Fleming and Rishel, Fleming (2004) Fleming and Stein, Øksendal, Platen,and Stein (2004) (2005)(2006).
} 
We have already discussed the constraints, and now turn to the Performance Criteria and the stochastic processes. The performance criterion used here is the standard one in the economics and finance literature ${ }^{11}$. Select a consumption ratio $c_{t}$ and a debt ratio $f_{t}=k_{t}-1$ to maximize the expectation (E) of the discounted value of the utility of consumption $\mathrm{U}\left(\mathrm{C}_{\mathrm{t}}\right)$ over an infinite horizon, subject to the debtor and creditor constraints above. The stochastic variables are described by vector $\Omega=(\mathrm{Y}, \mathrm{i}, \mathrm{N})$. The criterion function $\mathrm{V}$ is equation (6), which will be used for the debtor or creditor in the appropriate way below.

$$
\begin{aligned}
& \text { (6) } \mathrm{V}=\max _{c, f} E_{\Omega} \int U\left(C_{t}\right) e^{-\delta t} d t, \infty>t>0 . \\
& c=C / X, f=L / X, k=K / X, 1=k-f, \Omega_{\mathrm{t}}=\left(\mathrm{Y}_{\mathrm{t}}, \mathrm{r}_{\mathrm{t}}, \mathrm{N}_{\mathrm{t}}\right)
\end{aligned}
$$

The utility function selected should severely penalize low consumption. In this way we avoid selecting a debt whose servicing would severely reduce consumption (equation 3.1), in the event that there are "bad shocks" to the stochastic variables: the GDP, real interest rate and exchange rate. This is consistent with Mann's view of what is an excessive debt or one that is so high that it endangers consumption. The finance literature, such as Merton (1990), uses utility function (6a) or (6b) where risk aversion (1$\gamma$ ) is positive. In equation (6b), the logarithmic function, risk aversion is unity $(\gamma=0)$. This is a nice function to use, because low consumption produces very large negative utility. ${ }^{12}$.

(6a) $\mathrm{U}\left(\mathrm{C}_{\mathrm{t}}\right)=(1 / \gamma) \mathrm{C}_{\mathrm{t}}^{\gamma}, \quad(1-\gamma)>0, \gamma \neq 0$

(6b) $\mathrm{U}(\mathrm{Ct})=\ln \mathrm{C}_{\mathrm{t}}$.

The "discount rate $(\delta)$ " is just another way of specifying the effective length of the horizon. A high discount rate emphasizes near term consumption, and a low discount rate emphasizes far term consumption. The discount rate is a subjective variable, which may differ considerably between the debtor and creditor countries.

The inter-temporal optimization problem arises because the system is dynamic. Decisions taken at the present concerning the debt, capital and consumption have consequences for future consumption. A debtor has a positive $L>0$, and a creditor has a

\footnotetext{
${ }^{11}$ There are other very sensible criteria functions discussed in the papers of Fleming (2005) and Platen (2005).

${ }^{12}$ Negative values of $\gamma$ are fine and in that case there need not be a discount rate to make $\mathrm{V}$ finite.
} 
negative $\mathrm{L}<0$, debt. The inter-temporal optimization will determine if the country should be a debtor or a creditor, i.e., if the debt is positive or negative. The state of the system is described by net worth $\mathrm{X}_{\mathrm{t}}$ in equation (4), effective capital less debt. The dynamics of the system, which takes into account the uncertainties concerning the GDP, interest rate and exchange rate, is described by a stochastic differential equation for the change in net worth. The dynamic system at the core of inter-temporal optimization is the change in net worth $d X_{t}$. The change in net worth $\mathrm{dX}_{\mathrm{t}}$, equal to the change in effective capital less the change in debt, is precisely equal to $S_{t}$ saving.

The Gross Domestic Product $Y_{t}$ is the product of effective capital $K=P Q$ and its productivity $\beta_{\mathrm{t}}$, so that $\mathrm{Y}_{\mathrm{t}}=\beta_{\mathrm{t}} \mathrm{K}_{\mathrm{t}}=\beta_{\mathrm{t}}\left(\mathrm{P}_{\mathrm{t}} \mathrm{Q}_{\mathrm{t}}\right)$ is the GDP. Effective capital is the product of the "quantity" Q times its "quality" $\mathrm{P}$. The rate of technical progress $\mathrm{dP} / \mathrm{P}$ is the growth of the "quality variable". Both the productivity of effective capital $\beta_{\mathrm{t}}$ and the rate of technical progress $\mathrm{dP} / \mathrm{P}_{\mathrm{t}}$ are stochastic.

The change in net worth for the U.S., country 1 , is $\mathrm{dX}_{1 \mathrm{t}}$ equal to the change in effective capital $d(P Q)$ less the change in the debt $d L=(C+I+i L-\beta K) d t$, based upon equation (3.1).

(7) $d X_{1 t}=K_{t}\left(\boldsymbol{d} \boldsymbol{P}_{t} / \boldsymbol{P}_{\boldsymbol{t}}+\boldsymbol{\beta}_{\boldsymbol{t}} \boldsymbol{d t}\right)-\mathbf{i}_{\boldsymbol{t}} L_{t} d t-C_{t} d t=$ Saving

If there were no technical progress and no debt ${ }^{13}$, then saving would be the product of effective capital and its productivity $\beta_{t} K_{t}$ less $C_{t}$ consumption. If there is also technical progress then there is a bonus or real capital gain equal to $d P_{t} / P_{t}$ times effective capital $\mathrm{K}_{\mathrm{t}}$. In the absence of debt, saving $\mathrm{S}_{\mathrm{t}}=K_{t}\left(d P_{t} / P_{t}+\beta_{t} d t\right)-C_{t} d t$. This part is valid for either the debtor or the creditor country. Insofar as there is a dollar denominated debt, the saving is reduced by the net transfer payments $i_{t} L_{t} d t$. Real interest rate $i_{t}$ subsumes interest and dividends. Since the US debt is denominated in US dollars, there is no exchange rate involved in measuring the debt, when we ignore that the US also has foreign assets denominated in foreign currency.

The dynamic system at the core of inter-temporal optimization is the change in net worth $\mathrm{dX}_{\mathrm{t}}$. Equation (7) is a stochastic differential equation because the terms in bold letters are stochastic. They are: the productivity of capital plus the rate of technical progress in the first term, and the real rate of interest in the second term.

\footnotetext{
${ }^{13}$ A negative debt is a creditor position.
} 
The foreigner creditors hold US debt denominated in US dollars. Therefore the net worth of country 2 the foreign country $\mathrm{X}_{2 t}$ is equation (8), equal to capital $\mathrm{K}_{2}=(\mathrm{PQ})_{2}$ plus net foreign assets NL, where $\mathrm{L}$ is the US dollar denominated debt and $\mathrm{N}=$ foreign currency/\$US. A rise in $\mathrm{N}$ is an appreciation of the US dollar. The foreign creditors benefit from an appreciation of the US dollar. The change in net worth for the foreign country is equation (9). The difference from the US equation concerns the creditor position of the foreign country. The US debt $\mathrm{L}$ is an asset $\mathrm{N}_{t} \mathrm{~L}_{t}$ for the foreigner.

The effective interest rate for the creditor $r_{t}$ is the US real long term interest rate $i_{t}$ plus the appreciation of the US dollar, $\mathrm{dN}_{\mathrm{t}} / \mathrm{N}_{\mathrm{t}}$. The crucial stochastic variables for the foreign country are the productivity of capital $b_{t}$ and the effective real rate of interest $r_{t}=i_{t}$ $+\mathrm{dN}_{\mathrm{t}} / \mathrm{N}_{\mathrm{t}}$. equation (9a).

(8) $\mathrm{X}_{2 \mathrm{t}}=(\mathrm{PQ})_{2 \mathrm{t}}+(\mathrm{NL})_{2 \mathrm{t}}$

(9) $d X_{2 t}=K_{2 t}\left(d P_{t} / P_{t}+\beta_{t} d t\right)_{2}+\left(i_{t} d t+d N_{t} / N_{t}\right) N_{t} L_{t}-C_{2 t} d t=$ Saving

(9a) $d X_{2 t}=b_{2} K_{2 t}+r_{t} N_{t} L_{t} d t-C_{2 t} d t=$ Saving

The stochastic variables are the returns to capital $\mathrm{b}_{\mathrm{t}}=\left(d P_{t} / P_{t}+\beta_{t} d t\right)$ in both countries, the real rate of interest $\mathrm{i}_{\mathrm{t}}$ and $d N_{t} / N_{t}$, the appreciation ${ }^{14}$ of the US dollar. Variables $b_{t}$ and $i_{t}$ are relevant for the US, whose net liabilities are denominated in US dollars. For the foreign creditor, the exchange rate appreciation/depreciation $d N_{t} / N_{t}$ is also relevant.

A very important issue is how to describe the underlying stochastic processes, which will determine the optimal controls: the debt/net worth ratio, capital/net worth ratio and consumption/net worth ratio. A negative optimal debt ratio means that it is optimal for the country to be a creditor. There are two reasonable possibilities summarized in BOX 1 for the US. Each has a different solution for the optimal debt (positive or negative) ratio. The empirical characteristics of the two variables - the return and real interest rate - are discussed in the data part 5 below.

In the Prototype Model $^{15}$, it is assumed that both variables can be characterized as Brownian Motion/random walks with drift- BOX1, column 2/equations (10a)-(10b).

\footnotetext{
${ }^{14}$ Variable $\mathrm{N}=$ foreign currency/\$US. If $\mathrm{dN}>0$, the dollar is appreciating and if $\mathrm{dN}<0$ the dollar is depreciating.

${ }^{15}$ The Prototype Model is fully discussed in Fleming and Stein (2004) and in Stein (2006).
} 
Brownian Motion [BM] should be viewed as a random walk in continuous time. The second possibility [BM/EMR] is that the return is Ergodic Mean Reverting [EMR], BOX1, column 3/equations (11a)-(11b) and the effective interest rate is as before (10b) Brownian Motion with drift. In case of the Prototype Model, the stochastic processes are that the return on capital $\mathrm{b}_{\mathrm{t}}$ is equal to a deterministic term, the mean $b$ without a time subscript, plus a stochastic term $\sigma_{b} d w_{b}$, with a zero expectation. The real interest rate $\mathrm{i}_{\mathrm{t}}$ has a deterministic mean r plus a stochastic term $\sigma_{r} d w_{r}$ with a zero expectation. In the second case, the return is Ergodic Mean Reverting (EMR) with a mean of $b$ with no time subscript, and a finite speed of convergence $\alpha$. The real interest rate is BM with drift.

BOX 1 Stochastic Processes

\begin{tabular}{|c|c|c|}
\hline Stochastic Variable & $\begin{array}{l}\text { Col. (2) } \\
\text { Prototype Model } \\
\text { BM/BM }\end{array}$ & $\begin{array}{l}\text { Col. (3) } \\
\text { EMR/BM }\end{array}$ \\
\hline $\begin{array}{l}\text { Return on capital: } \\
b_{t} d t=d P_{t} / P_{t}+\beta_{t} d t\end{array}$ & $\begin{array}{c}\text { (10a) } b_{t} d t=b d t+\sigma_{b} d w_{b} \\
\mathrm{E}\left(\mathrm{b}_{\mathrm{t}}\right)=\mathrm{b}, \operatorname{var}\left(\mathrm{b}_{\mathrm{t}}\right)=\sigma_{\mathrm{b}}^{2} \mathrm{dt} \\
\text { Not stationary }\end{array}$ & $\begin{array}{c}(11 a) d b_{t}=\alpha\left(b-b_{t}\right) d t+\sigma_{b} d w_{b} \\
(11 b) b_{t}=>N\left(b, \sigma_{b}{ }^{2} / 2 \alpha\right) \\
\text { Stationary }\end{array}$ \\
\hline $\begin{array}{l}\text { Real interest rate: } \\
i_{t} d t\end{array}$ & $\begin{array}{c}(10 b) i_{t} d t=r d t+\sigma_{r} d w_{r} \\
E\left(i_{t}\right)=r, \operatorname{var}\left(i_{t}\right)=\sigma_{r}^{2} d t \\
\text { Not stationary }\end{array}$ & $\begin{array}{c}(10 b) \text { i } d t=r d t+\sigma_{r} d w_{r} \\
\text { Not stationary }\end{array}$ \\
\hline
\end{tabular}

For the foreign country, we consider the same two cases with one change. Instead of the real interest rate $i_{t}$, we use the effective real interest rate $r_{t}=i_{t}+d N_{t} / N_{t}$. The treatment of the real exchange rate for the foreign country as an exogenous stochastic process is questionable, since it depends upon productivity and thrift in both countries ${ }^{16}$. For simplicity here, we ignore that important feedback and leave it for further research. Empirically, the mean appreciation $\mathrm{dN} / \mathrm{N}$ is zero, but there is considerable variance.

\footnotetext{
${ }^{16}$ This is developed in the NATREX model. See Stein (2006, chapters 4-6).
} 
Therefore, the mean interest rate is $\mathrm{r}$ in both countries, and the only difference in the interest rate equation for the two countries is the variance of the interest rate.

3. The solution for the optimal ratio of debt/net worth $f>0$ or net assets/net worth $f<0$.

We use the method of dynamic programming $(D P)$ to solve for the optimal ratios of debt/net worth $\mathrm{f}=\mathrm{L} / \mathrm{X}$, capital/net worth $\mathrm{K} / \mathrm{X}=\mathrm{k}=1+\mathrm{f}$, consumption/net worth $\mathrm{c}=$ $\mathrm{C} / \mathrm{X}$ for both countries. The stochastic processes state that the future is unpredictable even if we knew the consumption and investment that will be selected in each period. Hence the future debt at time $\mathrm{L}_{\mathrm{T}}$ in equation (3.2) is unknowable at present, even though the consumption and investment policies are predetermined. That is why the SOC/DP approach is the foundation of our analysis.

Solve for (f, k, c) that maximize performance criterion (6) given the dynamics of net worth (7) or (9), and the alternative stochastic processes involving the return on capital and the real interest rate in BOX 1. The DP method of solution is quite technical and the reader is referred to Fleming and Stein (2004), Fleming and Soner (2005), Fleming and Rishel (1975), and Stein (2006), (2004) (2005) for the derivations and proofs. Here, we shall try to present the results and arguments in a "reader friendly" way.

The solution for the optimal debt/net worth $f\left(z_{t}\right)$ is equation (12), where as we explain below $z_{t}$ is a risk adjusted net return. This equation is graphed as figure 3 for a general case, applicable to either a debtor or a creditor country. When $\mathrm{f}$ is positive, it is optimal to be a debtor, and when $\mathrm{f}$ is negative it is optimal to be a creditor. The optimal debt/net worth denoted $f(z)$ is a linear function of $z$ the risk adjusted net return. The numerator of $\mathrm{z}$ is the net return - the return on capital less the effective real interest rate and the denominator is the risk. Both depend upon the stochastic processes, as discussed below. We use equation (12)/figure 3 in describing the solution to either the Prototype Model or the EMR/BM model described above. The optimal debt ratio for the US is $L_{t} / X_{t}$. (12) $f(z)=L_{t} / X_{t}=z /(1-\gamma)+f(0)=(b-r) /(1-\gamma) \sigma^{2}+f(0)$

The abscissa plots the risk adjusted net return, $\mathrm{z}=(\mathrm{b}-\mathrm{r}) / \sigma^{2}$. The slope of the line is $1 /(1-\gamma)$ the reciprocal of risk aversion. The intercept $f(0)$ is the optimal debt ratio when the mean net return is zero. Intercept $f(0)$ is precisely the value of debt/net worth that minimizes risk. Figure 3 is drawn for the case where, at zero net return, the country is 
neither a debtor nor a creditor. In the case of BOX1/column 2, the risk adjusted net return is equation (13a). The numerator (b-r) is the mean return on capital less the mean real interest rate. The denominator is $\operatorname{var}\left(b_{t}-i_{t}\right)$ the variance of the difference between return on capital and the real interest rate. In the case of BOX1/column 3, the risk adjusted net return is equation (13b). The numerator $\left(b_{t}-r\right)$ is the current value of the return less the mean value of the real interest rate. The denominator is the variance of the real interest rate.

(13a) $z_{t}=(b-r) / \operatorname{var}(b-i) \quad$ Box1/column 2

(13b) $z_{t}=\left(b_{t}-r\right) / \operatorname{var}(i) \quad$ BOX1/column 3

So far, we have been looking at the situation from the point of view of the debtor, the U.S. The situation viewed from the creditor's side is symmetrical, and can also be described by equations (12) - (13) and figure 3. Since it has been assumed that the creditor bears the exchange risk, the variance of the effective interest rate for country 2 includes the variance of the exchange rate. 
Figure 3. Optimal Debt/Net Worth linear function of risk adjusted net return

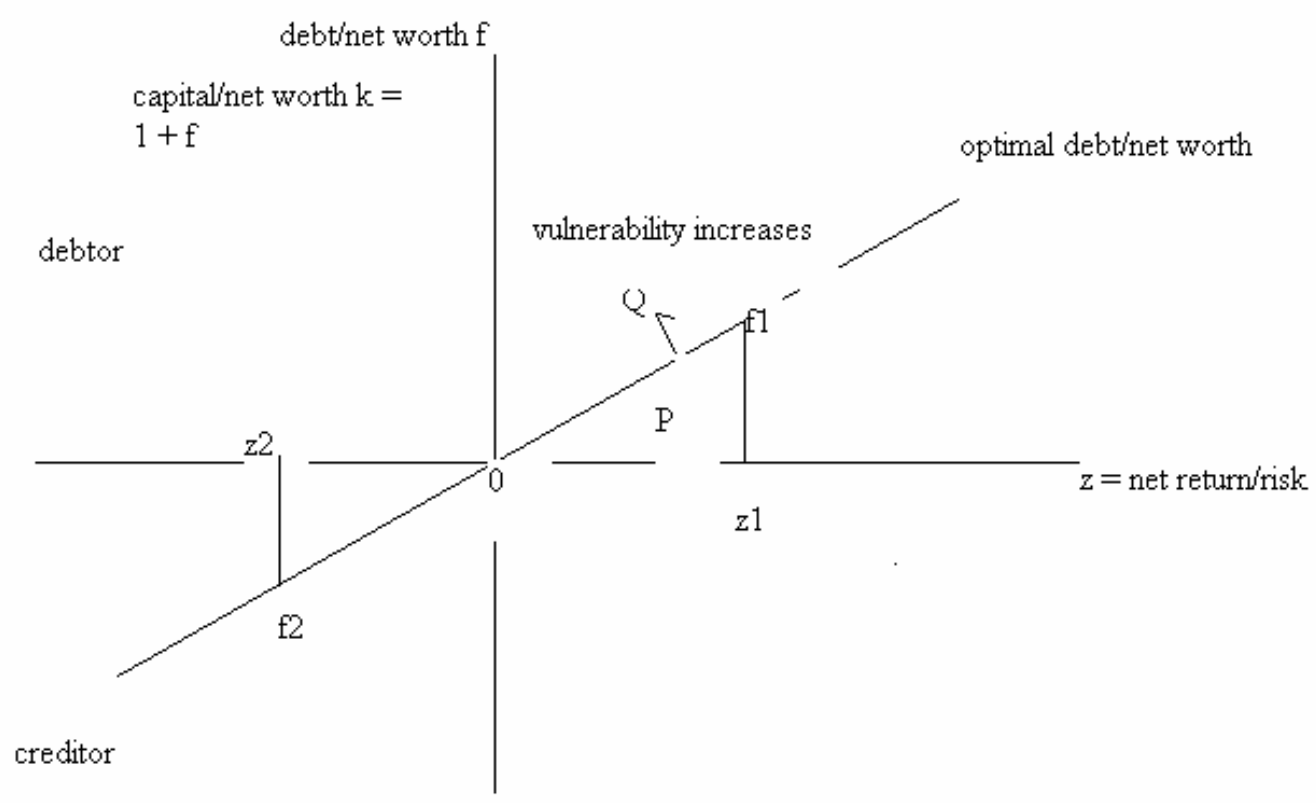

Figure 3. Optimal debt/net worth $\mathrm{f}$ equation (12) is a linear function of the risk adjusted mean net return $\mathrm{z}=(\mathrm{b}-\mathrm{r}) / \sigma^{2}$. Debtor country is at $\mathrm{z}=\mathrm{z} 1$ and creditor country is at $\mathrm{z} 2$. In the figure, $\mathrm{f}(0)=0$, a country is neither a debtor or a creditor if the risk adjusted net return is zero. Both countries have the same risk aversion. Slope of the line is $1 /(1-\gamma)$ the reciprocal of risk aversion.

The US is country 1 and the rest of the world is country 2. The optimal debt/net worth ratio is $f_{1}$ for the US and $f_{2}$ for the foreign country, according to equations (12) and (13). In figure 3 , the US has a risk adjusted return of $\mathrm{z} 1$ and an optimal debt ratio of $\mathrm{f}_{1}$. Country 2 has a risk adjusted return of $\mathrm{z} 2$ and an optimal debt ratio of $\mathrm{f}_{2}$. Figure 3 describes a situation where both countries have the same risk aversion $(1-\gamma)$ and the intercept $f(0)$ is zero. The latter condition means that if domestic return on capital were equal to the effective interest rate, $b=r$, the country would neither be a debtor or a creditor. The risk aversion coefficient determines the slope of the line. The lower is risk aversion , the greater is the slope of the line and the greater is the optimal debt ratio, for any risk adjusted net return. The appropriate measure of the risk adjusted net return $\mathrm{z}$ 
depends upon the stochastic process, as summarized in BOX 1 and equations (13a) and (13b).

The optimal capital/net worth follows immediately from the equations (12) and the definition of net worth $\mathrm{X}=\mathrm{K}-\mathrm{L}$. The country with a positive risk adjusted net return $\mathrm{z}>$ 0 will borrow to finance capital formation. Its capital/net worth $\mathrm{k}=1+\mathrm{f}$ can be read directly from the vertical axis in figure 3.

A frequently asked question is whether the foreigners are willing to hold the US debt? Will the optimal amount of US debt supplied $\mathrm{X}_{1} \mathrm{f}_{1}$ be equal to the optimal amount $\mathrm{X}_{2} \mathrm{f}_{2}$ that the foreigners want to hold ${ }^{17}$ ? Equations (12) and (13) are necessary but not sufficient to determine the optimal debt ratio. One must impose a "market balance" constraint, that the optimal debt supplied by the debtor must be equal to the optimal debt demanded by the creditor. The equilibrating variable is the mean real rate of interest. The market balance solution is as follows.

Market balance, when both countries select the optimal debt ratios is equation (14). The optimal supply of US debt is $X_{1} f_{1}$ and the optimal debt supplied by the foreigners is $X_{2} f_{2}$ based upon equation (12), assuming that $f(0)=0$. Each country $(j=1$, 2) has a return on capital $b_{j}$ and risk $\sigma_{j}^{2}$ as described above. Substitute equations (12) for both countries into (14), and derive equation (15). Parameters $\xi$ and $\mathrm{R}$ are defined in (a) and (b). This is market balance when each country selects the optimal debt ratio and the US debt supplied is the optimal quantity demanded by the foreigners.

(14) $X_{1} f_{1}+X_{2} f_{2}=0 \quad X_{j}=$ net worth of country $j$.

(12) $f_{j}=\left(b_{j}-r\right) /\left(1-\gamma_{j}\right) \sigma_{j}^{2}, \quad$ Optimal debt/net worth, $j=1,2$

(15) $\xi\left(b_{1}-r\right) / R_{1}+(1-\xi)\left(b_{2}-r\right) / R_{2}=0$.

(a) $\xi=X_{1} /\left(X_{1}+X_{2}\right)$, fraction of world net worth owned by country 1 .

(b) $R_{j}=\left(1-\gamma_{j}\right) \sigma_{j}^{2}$, product of risk times risk aversion in the $\mathrm{j}$-th country.

The common world rate of interest in equation (16) is a weighted average of the productivity of capital in each country $b_{\mathrm{j}}$, where weight $m$ is defined in equation (17). The

\footnotetext{
${ }^{17}$ The debt ratio of a country is $\mathrm{f}>0$. When $\mathrm{f}<0$, the country is a creditor.
} 
world mean rate of interest depends upon the risk, risk aversion ${ }^{18}$ and productivity of capital in both countries. .

(16) $r=b_{1} m+b_{2}(1-m)$

(17) $\left.\mathrm{m}=\left(\xi / \mathrm{R}_{1}\right) /\left[\left(\xi / \mathrm{R}_{1}\right)+(1-\xi) / \mathrm{R}_{2}\right)\right]$

The risk is the variance $\sigma^{2}=\operatorname{var}(\mathrm{b}-\mathrm{r})$, according to the stochastic process summarized in BOX 1. The currency denomination of the debt enters in the risk if the asset or liability is denominated in the currency of the counterpart country. The expected depreciation of the US dollar $\mathrm{dN} / \mathrm{N}$ is realistically assumed to be zero. Although the mean rate of interest does not include the exchange rate, there is a variance to the exchange rate, so that it does appear in the variance term for one of the countries. If the country faces no exchange risk, then the variance of $r$ is just the variance of the interest rate. If it does face an exchange risk, then the variance of $r$ is the variance of the sum of the interest rate and the exchange rate depreciation.

Solve for the optimal debt ratio when both the debtor and creditor countries are optimizing (equation (12) for each country respectively) and there is market balance (equation 14/15). In that situation the optimal US debt is no menace, but reflects optimization on the part of all countries.

Substitute the equilibrium interest rate equation (16) into equation (13a) or (13b) for each country to derive the risk adjusted return. For simplicity assume that net worth is the same in the US and in the rest of the world, $\mathrm{X}_{1}(\mathrm{t})=\mathrm{X}_{2}(\mathrm{t})$

The US risk adjusted net return $\mathrm{z}_{1}=\left(\mathrm{b}_{1}-\mathrm{r}\right) / \sigma_{1}{ }^{2}$ will be positive if the mean return in the US exceeds that in the rest of the world. In that case, the net return in the foreign country $\left(b_{2}-r\right)$ will be negative. This is the situation described in equation (18a) for the US and (18b) for the rest of the world.

(18a) $b_{1}-r=(1-m)\left(b_{1}-b_{2}\right)>0$.

(18b) $b_{2}-r=-m\left(b_{1}-b_{2}\right)<0$

Substitute (18a) and (18b) into the optimal debt/net worth equation (12) for $\mathrm{j}=1,2$. Then equations (19a) and (19b) are the solutions for the optimal debt/net worth ratios for the US and for the creditor country respectively. Term $R_{j}=\left(1-\gamma_{j}\right) \sigma_{j}^{2}$ is risk times risk

\footnotetext{
${ }^{18}$ Figure 3 was drawn upon the assumption that both countries have the same risk aversion, but the mathematical analysis does not make this assumption.
} 
aversion. Risk aversion is a preference variable, which will differ among countries. Risk, the variance, will depend upon the stochastic processes relevant to each country.

The implications of these equations are discussed in the next section. We explain that the optimal debt ratio for the US does not depend upon which country bears the exchange risk. The currency denomination of the debt is irrelevant, since the Market Balance constraint is imposed. The optimum debt demanded by the creditor must be equal to the optimal debt supplied by the debtor.

$$
\begin{array}{lc}
(19 a) f_{1}=(1-m)\left(b_{1}-b_{2}\right) / R_{1}>0 & \text { debtor } \\
(19 b) f_{2}=-m\left(b_{1}-b_{2}\right) / R_{2}<0 & \text { creditor } \\
R_{j}=\left(1-\gamma_{j}\right) \sigma_{j}^{2} & \text { Risk aversion }\left(1-\gamma_{j}\right)>0 \text { times } \sigma_{j}^{2} \text { risk for country } \mathrm{j}=1,2
\end{array}
$$

Ratio m defined in (b) above.

\section{The Contributions of the Stochastic Optimal Control Analysis to the Debate}

The Stochastic Optimal Control/Dynamic Programming analysis provides both theoretical precision and quantitative answers to the issues raised by Mann. Bernanke questions (B1)-(B4) can be answered, and the debate between the Pessimists and Optimists can be evaluated, using the SOC/DP framework of analysis summarized in equations (12) and (19). In this section, we provide a theoretical explanation and in section 5, we apply the theoretical framework to the data.

Bernanke and the International Monetary Fund asked whether from a global perspective it desirable that the rich US should be borrowing in the international capital market from the capital poor countries. The Optimists and Pessimists disagreed whether the US current account deficits and resulting external debt are menaces that require urgent correction. Will the foreigners be content to hold the growing amount of debt resulting from US current account deficits? Each side raised significant issues. The main problem was they did not provide an objective theoretical framework that can be empirically implemented to obtain quantitative estimates and thereby resolve the issues.

Figure 4 based upon equations (12) and (19) is helpful in answering these questions in a "reader friendly" way ${ }^{19}$. It relates the optimal debt supplied or demanded as a function of the real rate of interest. The equation of each curve in figure 4 for $j=1,2$,

\footnotetext{
${ }^{19}$ The underlying technical issues, derivations and proofs are in Stein (2006, ch. 9).
} 
when $f(0)=0$ is $(12 a)$, which is just another way to write equation (12).

(12a) $r=b_{j}-\left(1-\gamma_{j}\right) \sigma_{j}^{2} f_{j},=b_{j}-R_{j} f_{j}$

For expositional simplicity, the situation in figure 4 assumes that net worth is the same in both countries $\mathrm{X}_{1 \mathrm{t}}=\mathrm{X}_{2 \mathrm{t}}$. This is a special case of the mathematical solution above. Curve US $(j=1)$ is the optimal US debt supplied, and curve ROW ( $j=2)$, is the optimum demand for US debt by the rest of the world. If the real rate of interest is $r=b 1$, then the US will be neither a debtor nor a creditor. The higher the real rate of interest, the lower the debt supplied. The slope of the curve is $-\mathrm{R}_{1}$, minus the product of risk times risk aversion. Curve ROW is the optimal US debt demanded by the rest of the world. At a real rate of interest $r=b 2$, the rest of the world will be neither a debtor nor a creditor. The higher the real rate of interest on US debt, the greater the amount of US debt demanded. The slope of the ROW curve is $\mathrm{R}_{2}$, the product of risk and risk aversion in the rest of the world.

The Market Balance at point $P=\left(r, f^{*}\right)$, is the general equilibrium solution. It simultaneously determines the (i) equilibrium real rate of interest and (ii) $\mathrm{f}^{*}$ the optimum debt supplied by the US is equal to the optimal US debt demanded by the rest of the world, $f^{*}=f_{1}=-f_{2}$. The optimal US debt supplied and demanded is $L_{t}=f^{*} X_{t}$ and grows with the rate of growth of net worth. This is a sustainable and optimal situation, where the US is supplying the optimal debt and the rest of the world is optimally holding the US debt. In the Prototype Model BOX 1/column 2, the optimal debt ratio $\mathrm{f}_{\mathrm{j}}=\mathrm{f}^{*}$ (in equation (12)) is constant. At these optimal debt ratios, each country is maximizing the expected discounted value of consumption over an infinite horizon. This answers the question of how large a debt is optimal for both countries. 
Figure 4. General Equilibrium. Optimal debt supplied $\mathrm{f}_{1}$ by US, Optimal debt demanded $\mathrm{f}_{2}$ by rest of world ROW.

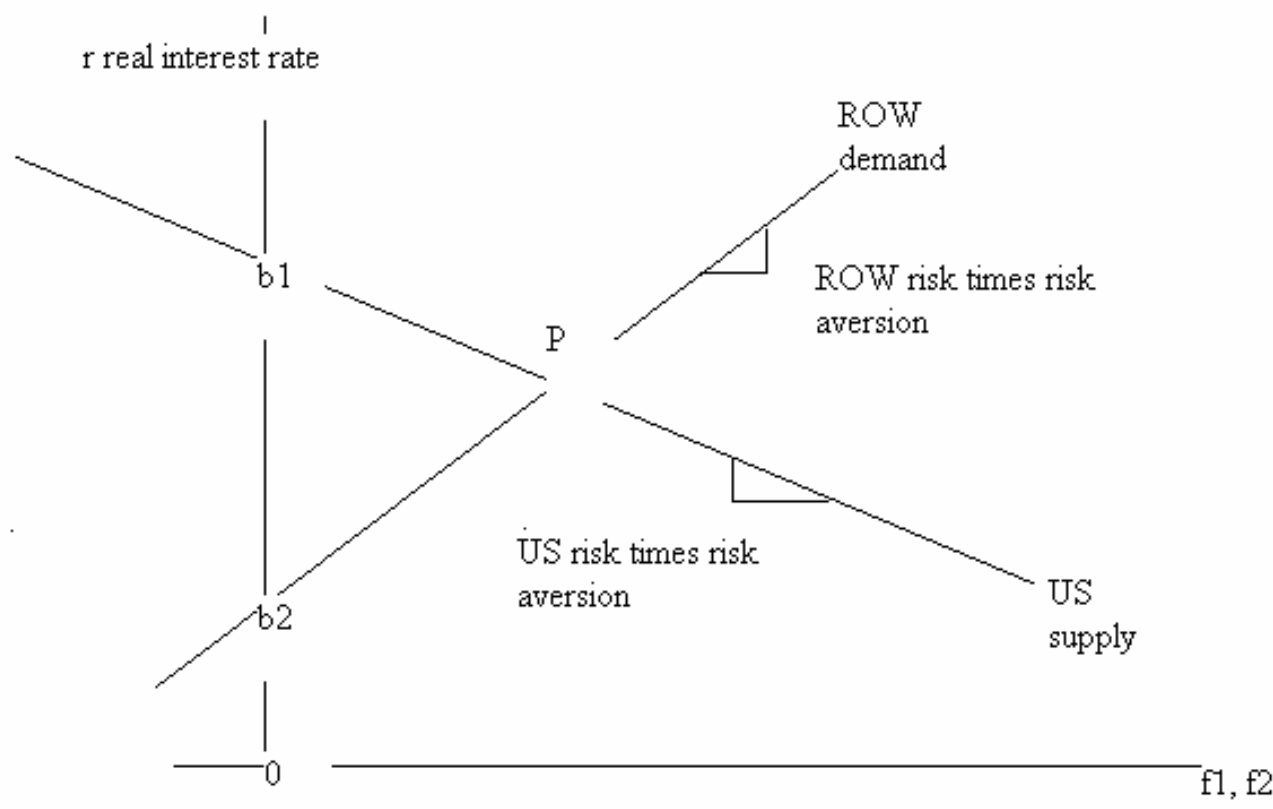

f1 = optimal US debt suppliedinet worth; f2 = optimal US demandedinet worth by KOW

Figure 4. General Equilibrium Solution. Market Balance solution for world real interest rate and equality of optimal US debt supplied and optimal US debt demanded by the rest of the world, when net worth is the same in both countries.

\subsection{Should the US be a debtor to the rest of the world ?}

There is a widespread consternation why the richest country in the world the US should be a debtor to the rest of the world ${ }^{20}$. The consternation is derived from the simple NeoClassical model that assumes countries have similar smooth concave production functions in capital and labor and that international differences in the return on capital are related to the corresponding differences in the capital/labor ratio ${ }^{21}$. R. Rajan (2006) of the International Monetary Fund argues that reforms are needed to reverse the paradox that the poor countries are financing the rich United States. The answer to the "paradox" is

\footnotetext{
${ }^{20}$ See both Bernanke's views stated above and the International Monetary Fund, WEO, Sept. 2005, p.100.

${ }^{21}$ This type of thinking led to the prediction that, upon the German reunification, the productivity of capital would be much higher in East Germany than in the West. Thereby there would be capital inflow and a higher growth rate in the East.
} 
derived from our analysis, which is summarized in equations (19a) and (19b) figure 4, and equation (12) figures 3 . Who should be the debtor and who should be the creditor depends upon $z$ the risk adjusted net return capital. According to equations (19a)-(19b), it is optimal for the US (country 1$)$ to be a debtor country to the rest of the world if $\mathrm{z}=\left(b_{1}\right.$ $\left.b_{2}\right) / R_{1}>0$, if the risk adjusted return on capital is higher in the US. This is the situation graphed in figure 4. It is an empirical question whether $\mathrm{Z}$ is higher or lower in the US than in the creditor countries. This issue is discussed in part 5 below.

\subsection{Currency denomination and effects of risk times risk aversion}

Catherine Mann and others claim that the denomination of the US debt in US dollars allows the US to have a larger debt than if it were denominated in foreign currency, because there is a smaller exchange rate risk. That view ignores the fact that the foreigners would be incurring the exchange rate risk and that their optimal demand for US debt would thereby be affected. Equations (19a)-(19b) graphed in figure 4 explain why the optimal US debt is affected by the risk times risk aversion in both countries.

Specifically, in the simple but realistic case where net worth is equal in both countries, the optimal equilibrium ratio $f$ in equations (19a) and (19b) is (20). The denominator $\mathrm{R}$ is the sum of risk times risk aversion in the two countries $R_{j}=\left(1-\gamma_{j}\right) \sigma_{j}{ }^{2}$. (20) $f_{1}=-f_{2}=\left(b_{1}-b_{2}\right) / R, \quad R=R_{1}+R_{2}$.

It is the sum $\mathrm{R}$ of risk times risk aversion in the two countries that is relevant for the optimal debt of the US, not the risk times risk aversion of the US by itself. For example, the US debt is denominated in US dollars, so that the risk is just $\sigma_{1}{ }^{2}=\operatorname{var}\left(\mathrm{b}_{1}-\mathrm{i}\right)$ the variance of the difference between the return on capital and the real interest rate, but not the variance of the exchange rate. The slope of the curve US is minus risk times US risk aversion. The foreign country must therefore bear the exchange risk. Therefore the risk for the foreign country $\sigma_{2}{ }^{2}=\operatorname{var}\left(b_{2}-r\right)$, where $r=$ real interest rate i plus exchange rate depreciation $\mathrm{dN} / \mathrm{N}$, as stated in equation (9a) above. The slope of the foreign curve ROW is risk times risk aversion.

Let the initial equilibrium be at point $\mathrm{P}$ in figure $4 . \mathrm{R}_{2}$ risk times risk aversion in the rest of the world ROW may rise either because there is more of an exchange risk or that they become more risk averse. Their demand for US debt declines. The ROW curve 
going through $b_{2}$ becomes steeper. The world rate of interest rises, to produce market balance. The rise in the mean world rate of interest decreases the US net return $\left(b_{1}-r\right)$ and, in turn, the US debt supplied declines. The equilibrium optimal US debt ratio moves from $\mathrm{P}$ in the direction of North-West. Similarly, if $\mathrm{R}_{1}$ risk times risk aversion in the US rises, then the curve in figure 4 labeled US going through return $b_{1}$ becomes steeper/more negative. The optimal debt supplied by the US declines, and the real interest rate declines. The foreign demand for US debt declines accordingly. Because the optimal debt ratio is inversely proportional to $\mathrm{R}$ world risk times risk aversion, it does not matter which country bears the exchange risk ${ }^{22}$. Equation (20)/figure 4 is quite general. There can be significant differences in risk times risk aversion in the two countries.

\subsection{Vulnerability}

Catherine Mann correctly stressed that an "unduly large" external debt is a menace insofar as it would endanger the level and growth of consumption ${ }^{23}$. The SOC/DP analysis makes this view precise and operational. Equation (3.1) above shows how the level of consumption is stochastic because the GDP, real interest rate and exchange rate are stochastic. Specifically, the stochastic effects upon consumption come from the stochastic net return. We explain precisely what is an "unduly large" external debt burden net payments to foreigners/GDP, that makes the economy more "vulnerable' to shocks.

Define Vulnerability to shocks as the probability that shocks to the net return will lead to a decline in consumption. The relation between vulnerability and debt ratios can be described by the distribution function of the growth rate of consumption in figure 5. The probability of a decline in the level of consumption, which is a negative growth of consumption, is the area under the curve to the left of the origin. The area under the curve to the left of the origin is directly related the deviation of the actual debt ratio from the optimal ratio. This proposition is proved in Fleming and Stein (2004) and in Stein (2006, ch. 3). The greater is the area under the curve to the left of the origin, the more vulnerable the economy is to external shocks.

\footnotetext{
${ }^{22}$ Figure 3 was drawn on the assumption that there is a common value for risk aversion (1- $\gamma$ ), but different risk adjusted net returns. This was just done for visual clarity and facilitates the exposition and interpretation of the empirical results.

${ }^{23}$ See section (2.1) above.
} 
The optimal debt ratio is $\mathrm{f}\left(\mathrm{z}_{1}\right)$ and total debt is $\mathrm{f}\left(\mathrm{z}_{1}\right) \mathrm{X}_{1}(\mathrm{t})$ in figure 3. At this debt ratio, the expected growth rate of consumption and net worth is maximal, for any given ratio of consumption to net worth. In this case, the debt is financing productive investment such that the ratio of capital/net worth $\mathrm{k}=1+\mathrm{f}\left(\mathrm{z}_{1}\right)$.

If the debt rises because it is financing consumption rather than productive investment, then the actual debt will rise - and net worth will decline ${ }^{24}$ - without a corresponding rise in $\mathrm{z}$ the risk adjusted net return. As the actual debt ratio rises from $\mathrm{P}$ to Q above the line in figure 3, then the distribution function of the growth rate of consumption in figure 5 shifts to the left with a lower mean and higher variance ${ }^{25}$.

When bad shocks occur to the return and interest rate, there is an increase in the probability of a decline in consumption and net worth. That is why the vulnerability of the economy to bad shocks increases continuously as the debt ratio exceeds the optimal ratio. This proposition, derived from our SOC/DP analysis, allows one to evaluate the arguments of the pessimists and the optimists.

\footnotetext{
${ }^{24}$ Recall that net worth X equals capital K less debt L.

${ }^{25}$ The method of thinking here is very similar to that of Value at Risk VaR concept in the finance literature.
} 
Figure 5. Probability distribution function of the growth of consumption. Vulnerability is the probability of a decline.

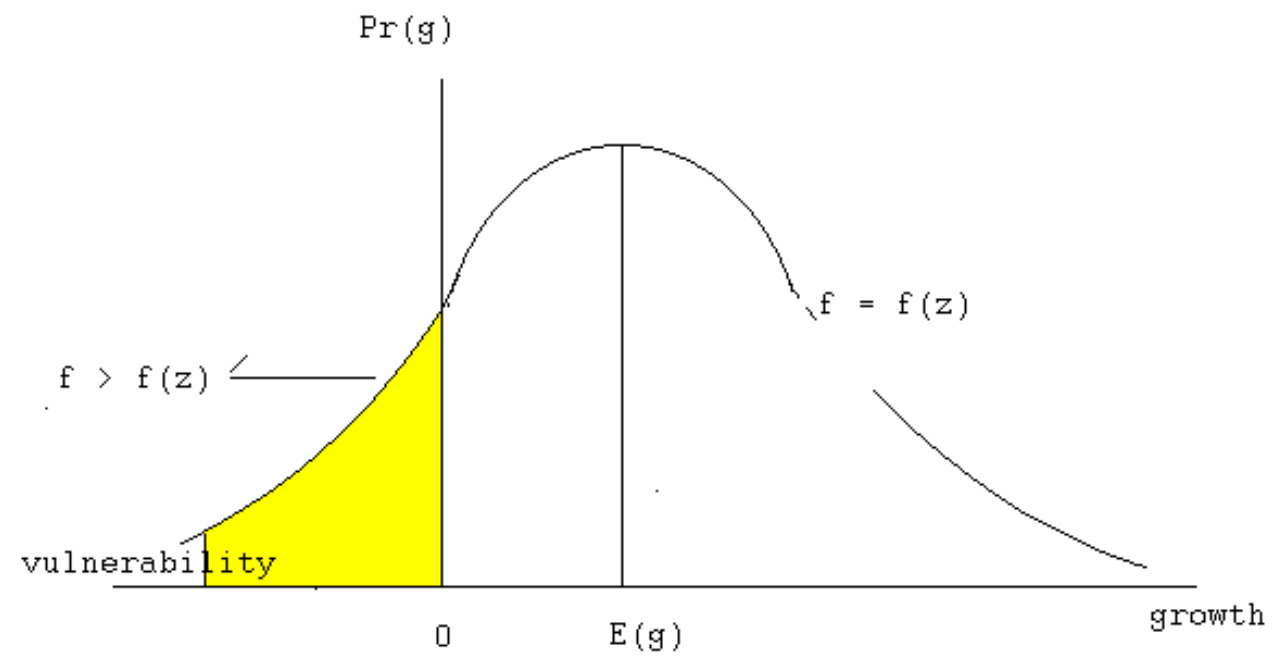

Figure 5. Vulnerability to shocks from the return or effective interest rate is the probability that they will reduce the rate of consumption. This is the region where growth of consumption is negative. If the actual debt ratio $f(t)$ exceeds the optimal $f(z)$, the mean of the distribution shifts to the left and the variance increases. The probability increases that consumption declines. .

4.4 Effect of foreign productivity of capital upon optimal US debt and current account deficit

The analysis above explains how the foreign productivity of capital affects the optimal US debt/net worth, US capital/net worth and current account deficit. Start with US as a debtor and the rest of the world as a creditor, point $\mathrm{P}$ in figure 4 , where $\mathrm{f}_{1}=-\mathrm{f}_{2}=$ $\left(b_{1}-b_{2}\right) / R$ is positive ${ }^{26}$.

Let the return on capital $b_{2}$ in the foreign country decline. The ROW curve shifts downward with a lower intercept but the same slope. The ROW curve shifts down and intersects the US curve to the right of P. Then the optimal net US assets demanded by the foreign country rises. The world rate of interest declines and induces an increase in the

\footnotetext{
${ }^{26}$ This form of the equation assumes that net worth $X_{1}=X_{2}$.
} 
optimal debt supplied by the US. The new market balance situation is that the optimal US debt has risen due to the decline in the foreign rate of return.

The optimum US current account deficit follows directly. In the Prototype Model, the ratio of debt/net worth $=f^{*}$ is constant. The current account deficit $d L_{t}=f^{*} d X_{t}$. In the partial equilibrium analysis (equation 12/figure 3) the ratio of the current account deficit/net worth is equation (21a). The growth rate of net worth $d X_{t} / X_{t}$ is denoted $g_{t}$. The value of the optimal expected growth rate is derived in Fleming and Stein (2004), Stein (2005) (2006, ch. 3). In the general equilibrium analysis (BOX 2/figure 4), the optimal current account deficit/net worth is equation (21b).

(21a) $d_{L_{t}} / X_{t}=\left[(b-r) /\left(1-\gamma_{1}\right) \sigma_{1}^{2}\right] g_{t}$

(21b) $\mathrm{dL}_{\mathrm{t}} / \mathrm{X}_{\mathrm{t}}=\left[\left(\mathrm{b}_{1}-\mathrm{b}_{2}\right) / \mathrm{R}\right] \mathrm{g}_{\mathrm{t}}$

In both cases, it is optimal for the US to have current account deficits if the net return - the term in brackets - is positive. The important quantitative questions are: how large should the deficit be? Should it be constant? We discuss these issues in part 5 below.

5. Evaluation of arguments of Pessimists and Optimists on the basis of Stochastic Optimal Control/ Dynamic Programming Model

\subsection{Research design}

The views of the Pessimists and the Optimists are insightful, but they are not based upon a consistent framework of analysis that can provide quantitative answers to Bernanke's questions (B1)-(B4) in part 1 above. They cannot explain: What is an operational quantitative meaning to the terms "sustainable" and "vulnerable." Unless that is done, one cannot answer the questions: Is the U.S. external debt a cause for alarm? Are US current account deficits/GDP leading to an "unsustainable" situation? We derived optimization equations for the debt ratio and determined which country should optimally be the creditor and which one should optimally be the debtor. Vulnerability of consumption to shocks is positively related to the difference between the actual and optimal debt ratio.

We analyze the situation in several ways that are summarized in BOX 2, based upon equation (12)/figure 3 and equations (19a)-(19b),(20)/figure 4. Objectively, there 
are two alternative stochastic processes, summarized in BOX 1. We can view the optimal debt ratio either directly from the partial equilibrium point of view of the US, where the real rate of interest is given (equation 12), or from the general equilibrium point of view where both the US and the ROW are holding the optimal amounts of debt or foreign assets and there is also market balance (equations 19a-19b, 20, figure 4). The ROW is optimally holding the US debt, which is optimally supplied. The optimal capital/net worth ratio $\mathrm{k}=$ $1+\mathrm{f}$. 
BOX 2

Optimal debt/net worth $\mathrm{f}=\mathrm{k}-1, \mathrm{k}=$ capital/net worth

[A][B] partial equilibrium optimization.
$[A] f=$ mean $(b-r) /(1-\gamma) \sigma^{2}$
$\sigma^{2}=\operatorname{var}(b-r)$
$[B] f=\left(b_{t}-\right.$ mean $\left.r\right) /(1-\gamma) \sigma^{2}$
$\sigma^{2}=\operatorname{var}(\mathrm{r})$

[C] general equilibrium optimization

$[C] f=\left(b_{1}-b_{2}\right) / R \quad R=R_{1}+R_{2}, \quad R_{j}=\left(1-\gamma_{j}\right) \sigma_{j}^{2}$

Symbols: $b_{j}=$ return on capital, country $\mathrm{j}=1,2$;

US: $\mathrm{r}=\mathrm{i}$ = real rate of interest; debt is denominated in US dollars;

ROW: $\mathrm{r}=\mathrm{i}+\mathrm{dN} / \mathrm{N} ; \mathrm{dN} / \mathrm{N}=$ dollar appreciation $(+) /$ depreciation $(-)$.

[A] = Prototype Model; [B] = Ergodic mean reversion for $b_{t}$, BM for r. [C] Countries have equal net worth. It is assumed that $\mathrm{f}(0)=0$, if $(\mathrm{b}-\mathrm{r})=0$, the country is neither debtor nor creditor. Risk aversion $\left(1-\gamma_{\mathrm{j}}\right)>0$.

There are two alternative stochastic processes ${ }^{27}$. In the Prototype Model BOX $1 /$ column 2 , both the return on capital $b_{t}$ and the real long term interest rate are described as Brownian Motion with drift [BM]. This implies [A] in BOX 2. The numerator of the risk adjusted net return is the mean net return (b-r) and the denominator $\sigma^{2}$ is the variance of the net return. The second case $E M R / B M$ is when the return on capital $\mathrm{b}_{\mathrm{t}}$ is ergodic mean reverting and the real rate of interest $r_{t}$ is Brownian Motion with drift: BOX 1/column 3. This implies [B] in BOX 2. The numerator of the risk adjusted net return is the current return $b_{t}$ less the mean real rate of interest. The denominator is the variance of the real rate of interest. Cases [A][B] refer to partial equilibrium equation (12)/figure 3, where the real rate of interest is exogenous. Insofar as the US debt is denominated in US dollars, there is no exchange risk for the US. Case [C] is based upon general equilibrium equations (19a)-(19b), (20)/figure 4, where the real rate of interest is endogenous. In case [C] the debt supplied by the US is exactly equal to the optimal US debt demanded by the

\footnotetext{
${ }^{27}$ The presentation here is "reader friendly". Technical details and proofs of the mathematical statements here are in Stein (2006, chapters 9 and 3), (2005).
} 
ROW. The appropriate measure of the net return and risk depends upon the stochastic process, as explained above.

In each case noted in BOX 2, we derive estimates of the optimal debt/net worth $\mathrm{f}\left(\mathrm{z}_{\mathrm{t}}\right)$ for the U.S. The only variable that is not objective is the preference variable, risk aversion $(1-\gamma)$, which is based upon a utility function. This implies that the level of the optimal debt depends upon preferences. However, for any arbitrary risk aversion the variation of the optimal debt is objectively measured. Then we convert the optimal debt/net worth ratio into the optimal ratio of debt/GDP denoted by $h\left(z_{t}\right)$ where the argument $\mathrm{z}_{\mathrm{t}}$ of net return indicates that we are referring to the optimal quantity. Estimates are derived for the actual ratio of US "debt"/GDP. Finally we can compare the actual to the optimal debt ratio and derive a measure of vulnerability $\Psi_{\mathrm{t}}=\mathrm{h}\left(\mathrm{z}_{\mathrm{t}}\right)-\mathrm{h}_{\mathrm{t}}$. In this manner we can evaluate the arguments of the Pessimists and the Optimists, and answer Bernanke's questions in an objective and quantitative manner. The SOC/DP mathematical analysis is a formal and precise counterpart to Mann's insightful analysis.

\subsection{Data $^{28}$}

\section{Return on capital}

In each case in BOX 2, we estimate the return on capital directly. In cases [A][B], the partial equilibrium approach, the real rate of interest is exogenous to the US. In case [C], the general equilibrium approach, the real rate of interest is endogenous and is determined by the optimum quantities of debt supplied and demanded.

There have been several different ways to compare the return to capital $b$ among countries $^{29}$. We choose the estimates that are most consistent with the optimization model. The return on capital for the country as a whole $d y / d K$ is equation (22). It is the change in real GDP divided by the change in capital. It can be expressed as the ratio of $(g=d y / y)$ the growth rate of the GDP divided by $(j=I / y)$ the ratio of real gross private domestic investment/GDP.

(22) $b=d y / d K=(d y / y) /(I / y)=g / j$.

\footnotetext{
${ }^{28}$ Almost all of the data used in this paper are from: Federal Reserve Bank of St. Louis, FRED. See Stein (2006, chapter 9) for details and for graphs of the relevant variables

${ }^{29}$ See International Monetary Fund WEO September 2005 Box 2.2.
} 
Variable $b$ in equation (22) expresses the additional output that is made available when there is capital formation. In some cases the output is used for wages, in others for reported profits of corporations or non-incorporated enterprises and in others for taxes. Variable $b$ is an all-inclusive measure of the social return on capital formation that can affect social consumption in equation (3). It captures all the sources income that constitutes the GDP. Moreover, the measured return in (22) is a real return and is not confounded by what has been happening in asset markets, such as bubbles.

In the partial equilibrium cases $[\mathrm{A}][\mathrm{B}]$ in Box 2, we also need the real long-term rate of interest $r_{t}$ to derive the net return. On the basis of the ADF statistics, the return $b_{t}$ is stationary/ mean reverting, but the real long term interest rate $r_{t}$ is not necessarily so. Hence the case [B] in BOX 2 is probably a better description than case [A]. Figure 6 is a histogram of the difference (b-r) called NETRETURN1. From the data ${ }^{30}$ underlying these figures, we derive both the net return $\left(b_{t}-r_{t}\right)$ and the variance $\sigma^{2}$.

Figure 6. Histogram and descriptive statistics of net return, $b_{t}-r_{t}$.

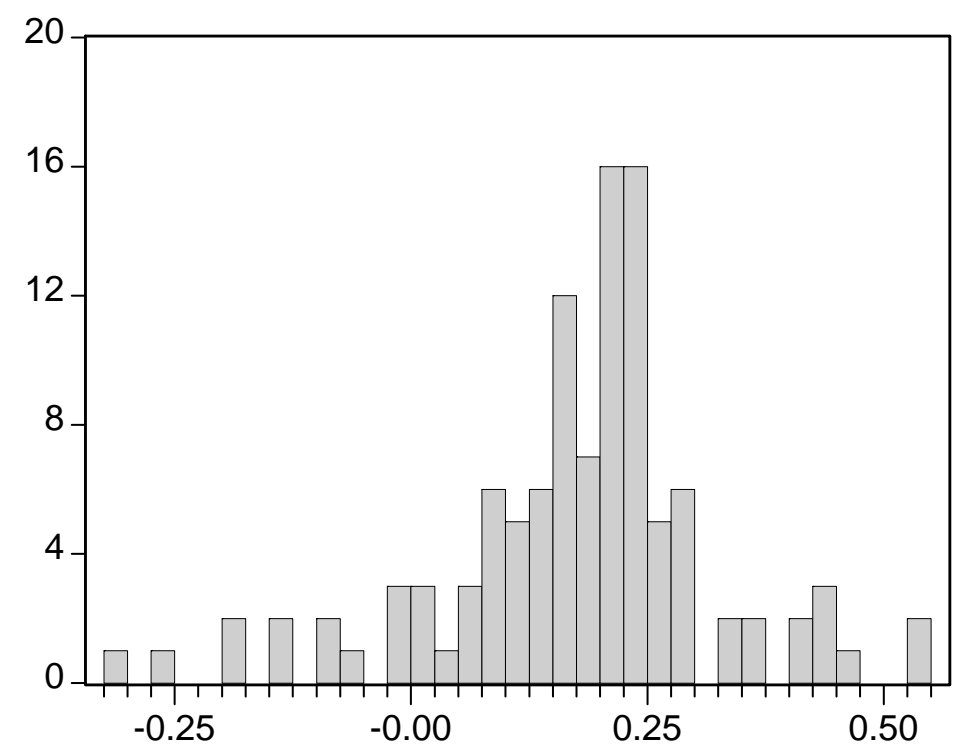

\begin{tabular}{|lr}
\hline \multicolumn{2}{|l|}{ Series: NETRETURN1 } \\
Sample 1977Q1 2004Q2 \\
Observations 110 \\
Mean & 0.175070 \\
Median & 0.201872 \\
Maximum & 0.539108 \\
Minimum & -0.310586 \\
Std. Dev. & 0.148278 \\
Skewness & -0.615181 \\
Kurtosis & 4.445887 \\
& \\
Jarque-Bera & 16.52008 \\
Probability & 0.000259 \\
\hline
\end{tabular}

Figure 6. Histogram and descriptive statistics of net return NETRETURN1 $=b_{t}-r_{t}$, where $b_{t}$ is the return and $r_{t}$ is the real long term interest rate.

\footnotetext{
${ }^{30}$ A full description of the data is in Stein (2006, chapter 9).
} 
In the general equilibrium case $[\mathrm{C}]$ where the real interest rate is endogenous, we need an estimate of the US less foreign returns $\left(b_{1}-b_{2}\right)$ on capital. It is done in the following way. Using the measure of return on capital in equation (22), the differential return is equation (23). It is expressed in terms of growth rates $g$, investment ratios $j$ between the US and foreign countries.

(23) $\left(\mathrm{b}_{1}-\mathrm{b}_{2}\right)_{\mathrm{t}}=\left[\left(g_{1} / \mathrm{j}_{1}\right)-\left(g_{2} / \mathrm{j}_{2}\right)\right.$

In fact the investment ratios for the US, Japan and the EU have been similar at $\mathrm{j}=$ $20 \%$ in recent years ${ }^{31}$. The US investment ratio has been relatively constant at this level since 1997. The differential return for the US (country 1) can be expressed as equation (23a). It is proportional to the difference in the returns on capital. The factor of proportionality is $1 / \mathrm{j}$.

(23a) $\left(b_{1}-b_{2}\right)=(1 / j)\left(g_{1}-g_{2}\right)$.

In the general equilibrium case [C] in BOX 2, the optimal debt/net worth ratio for the US is equation (24). It is proportional to the difference in growth rates, where the factor of proportionality $\alpha=1 / \mathrm{jR}$.

(24) $f(z ; \gamma)=\left(g_{1}-g_{2}\right) / j R=\alpha\left(g_{1}-g_{2}\right)$

The ratio $h$ of debt/GDP in equation (25) is derived from the ratio $f$ of debt/net worth in BOX 2 using the definition ${ }^{32}$ of net worth $\mathrm{X}=\mathrm{K}-\mathrm{L}$ (25) $h=L / Y=(L / X)(X / Y)=f / b(1+f), \quad b=Y / K$ is the productivity of capital. Thereby, measures of vulnerability $\Psi_{\mathrm{t}}=\mathrm{h}\left(\mathrm{z}_{\mathrm{t}}\right)$ - $\mathrm{h}_{\mathrm{t}}$ are obtained.

\section{Measurement of Net Liabilities}

The controversy between the Pessimists and the Optimists concerns the "external debt", which is a negative net international investment position (NIIP). If one claims that it is or is not a menace it is important to know what variable one is measuring. There are however difficult measurement problems ${ }^{33}$. First, the net assets (or debt when it is

\footnotetext{
${ }^{31}$ International Monetary Fund, WEO Sept. 2005, pp. 93-94.

32 The debt/net worth must exceed minus one.

33 See "Measuring a Country's Net External Position", International Monetary Fund, WEO (2005, April, Box 3.2, chapter III).
} 
negative) is a stock of claims in the form of equities, direct investment, long-term debt, short-term debt of the private and public sectors, bank claims and real estate, owned by the corporate and non-corporate sectors. It is difficult to measure the market values of these claims, just as it is difficult to measure the "capital" of a country. Second, the US has claims on foreigners denominated in foreign currency and liabilities to foreigners, which are generally denominated in US dollars. Third, the values of the claims fluctuate considerably, as a result of fluctuations in the stock market, real estate markets, interest rates and the exchange rate. If the foreign stock markets are booming, then the value of US assets abroad rises. If in addition the value of the dollar depreciates, then the dollar value of US assets abroad rises. Such price rises can increase the value of net foreign assets/decrease the value of net foreign debt - even though the current account of the US continues to be in deficit. Of course, the argument can go the other way. If the US stock and real estate markets appreciate rapidly and the value of the dollar rises, then the measured US net external debt rises. It would be most problematic to argue that the "external debt" is or is not a serious problem, when the measure of the net debt can fluctuate considerably as a result of bubbles in the real estate and stock markets, as well as from speculative short-term fluctuations in the exchange rate. We doubt that these valuation adjustments are useful to answer the question: Is the U.S. external debt a cause for alarm?

Our approach, which is quite common in the literature, is to measure the net asset position $\mathrm{W}(\mathrm{t})$ by cumulating the current account $w_{t}$ equal to net foreign investment. ${ }^{34}$ The net external assets are the sum of the current accounts from an arbitrary time $t=0$ up until the present, which is the integral on the right hand side of equation (26). The transitory capital gains or losses from the price effects are ignored, because they have means of zero and considerable variance ${ }^{35}$. Define $\mathrm{W}(\mathrm{t})$ as the "core net foreign assets". The "core net

\footnotetext{
${ }^{34}$ This is the series NETFI taken from FRED.

${ }^{35}$ The mean percentage change in the real value of the dollar, over our sample period, was -0.02 with a standard deviation of 0.24 . Hence the expected valuation adjustment due to exchange rate changes is not significantly different from zero.
} 
external debt", what we call "L", is the negative of $\mathrm{W}(\mathrm{t})$. Henceforth, when we refer to net foreign assets, it refers to the core ${ }^{36}$ measure $\mathrm{W}(\mathrm{t})$.

(26) $\mathrm{W}(T)=\int^{T} w_{t} d t+W(0), \quad T>t>0 \quad w_{t}=$ current account

Our sample period is 1977q1 - 2004q2. Assume that the net asset position at the initial date $t(0)=1977 \mathrm{q} 1$ is the capitalized value of the balance of investment income (the numerator), where the capitalization factor is the growth rate at that date (the denominator). Thus the initial position is that of the US is a creditor W(0) $=\$ 4.655\left(10^{9}\right)$ / $0.043=\$ 108.26\left(10^{9}\right)$ This gives us W(0). Subsequently the value of net external assets is derived recursively by adding the current account $\mathrm{w}(\mathrm{t})$ to obtain: $\mathrm{W}(\mathrm{t})=\mathrm{W}(\mathrm{t}-1)+\mathrm{w}(\mathrm{t})$. Divide the cumulative sum $\mathrm{W}(\mathrm{t})$ by the GDP of the period $\mathrm{y}(\mathrm{t})$ and derive a measure of the ratio of net external assets/GDP $=\mathrm{W}(\mathrm{t}) / \mathrm{y}(\mathrm{t})$. If $\mathrm{W}(\mathrm{t})$ is negative, it is a net debt. The results are not sensitive to the estimate of the initial external position $\mathrm{W}(0)$ because we are looking at the ratio relative to current GDP. At much later time, the initial value only contributes $\mathrm{W}(0) / \mathrm{y}(\mathrm{t})$ to our estimate of $\mathrm{W}(\mathrm{t}) / \mathrm{y}(\mathrm{t})$. As $\mathrm{y}(\mathrm{t})$ grows, this ratio declines to zero. Variable $\mathrm{h}_{\mathrm{t}}=$ net debt/GDP $=-W(\mathrm{t}) / \mathrm{y}(\mathrm{t})$, is the negative of the net external assets/GDP. The $\mathrm{h}_{\mathrm{t}}=$ debt/GDP and debt/net worth $\mathrm{f}_{\mathrm{t}}$ are related positively according to equation (25).

\section{Application of stochastic optimal control to controversies and questions}

Three empirical series are required to apply our theoretical analysis to evaluate the arguments of the Pessimists and Optimists and to answer Bernanke's questions. They are the risk adjusted net return for the US in the partial equilibrium analysis ([A][B]/Box 2), the risk adjusted differential return $\left(\mathrm{b}_{1}-\mathrm{b}_{2}\right) / \mathrm{R}$ in the general equilibrium analysis ([C]/BOX 2) and $h_{t}$ the debt/GDP ratio.

\subsection{General Equilibrium}

The optimal debt/GDP ratio for the US should be proportional to the difference in growth rates. Table 1 contains the means and standard deviations of the growth rates in the US, the Euro Area and Japan, annual data over the period 1991-2004. Figure 7 plots

\footnotetext{
${ }^{36}$ In measuring the rate of inflation, Central Banks have found it desirable to separate the volatile prices of food and fuel from the prices of the other commodities and derive a measure of the "core" rate of inflation. We do a similar thing for net foreign assets or net foreign debt.
} 
the difference in growth rates between the US and the Euro Area (USEUGROW) and the difference between the US and Japanese growth rates (USJPNGROW) for each year. It is evident that almost always the return on capital has been higher in the US ${ }^{37}$. Moreover, the risk adjusted growth rate $\mathrm{z}$, measured in table 1/row 3 as the ratio of the mean/standard deviation, is very much higher in the US than it is in either the Euro Area or Japan. For example, if the index of US risk adjusted return $\mathrm{z} 1=100$, the risk- adjusted rate of return in Japan z2 $=45$ and in the Euro area z3 $=74$. Therefore the optimal debt/net worth ratio $\mathrm{f}(\mathrm{z} 1 ; \gamma)$ for the US should be positive and negative for Japan and the Euro area. ${ }^{38}$. There is nothing paradoxical that: (i) the US should be debtor and that Japan should be a creditor and (ii) the US has current account deficits ${ }^{39}$ and Japan and the Euro area have current account surpluses.

\footnotetext{
${ }^{37}$ Over the period 1980-2004, the US switched from a creditor to a debtor country, and the Asia-Pacific Industrial countries, particularly Japan switched from debtors to creditors. See International Monetary Fund, WEO, April 2005, chapter III, page 112.

${ }^{38}$ The IMF (WEO, Sept. 2005, pp. 100-01) estimated internal rates of return on invested capital over the period 1994-2003. They estimated that it was $8.6 \%$ for the US, and in emerging Asia $-4.6 \%$. Hence even on that basis, the US should be a debtor country.

${ }^{39}$ See also figure 1 for the time path of the US current account/GDP.
} 
Figure 7. Difference between US growth rate and Japanese growth rate USJPNGROW and US growth rate and EU growth rate USEUGROW

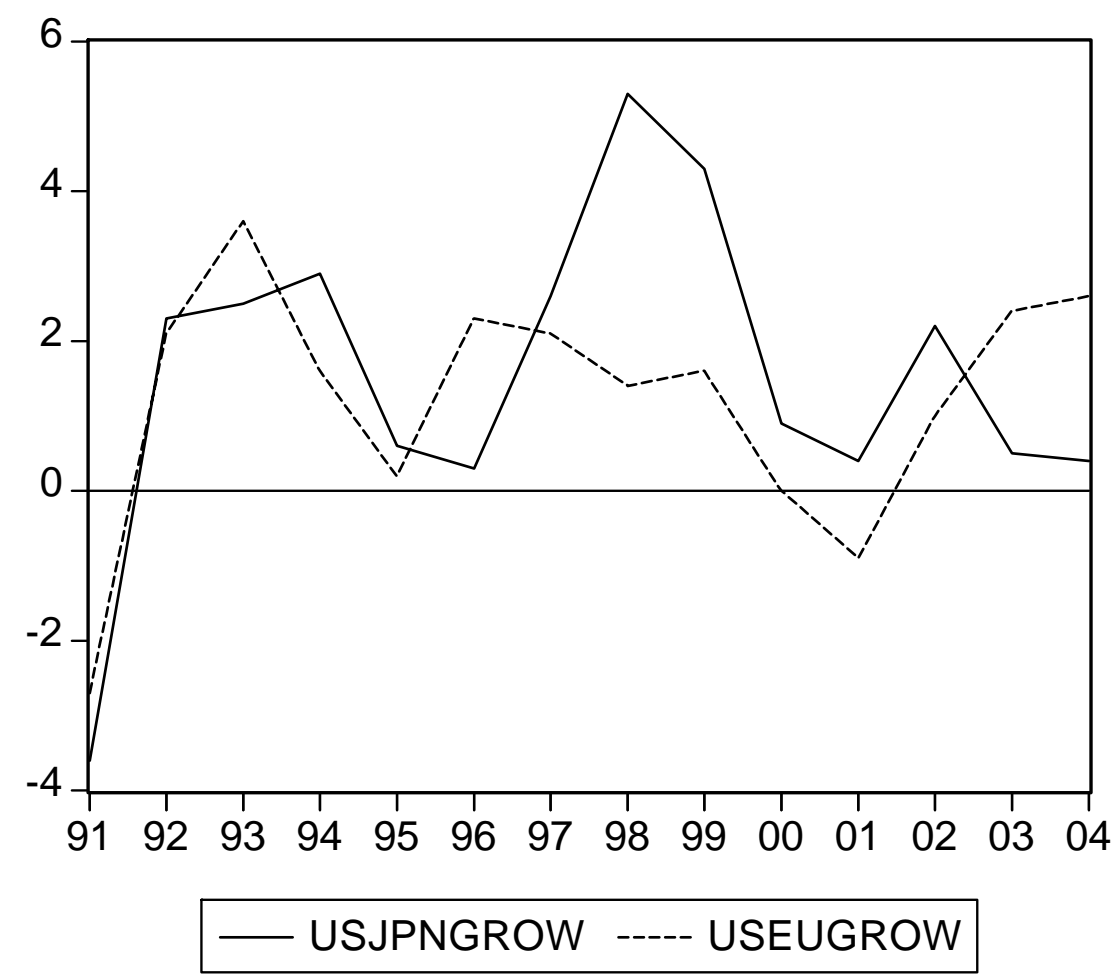

Figure 7. Difference between US and Japan (USJPNGROW), and between US and Euro (USEUROGROW), growth rates. 
Table 1

Growth rates of real GDP, 1991-2004 annual; Current account/GDP, in US, Euro area and Japan

\begin{tabular}{|l|l|l|l|l|l|l|}
\hline & $\begin{array}{l}\text { US growth } \\
\text { rate } \\
1991-2004\end{array}$ & $\begin{array}{l}\text { US Current } \\
\text { account/GDP } \\
2004\end{array}$ & $\begin{array}{l}\text { Japan } \\
\text { growth rate } \\
1991-2004\end{array}$ & $\begin{array}{l}\text { Japan } \\
\text { current } \\
\text { account } \\
\text { /GDP } \\
1997-2004\end{array}$ & $\begin{array}{l}\text { Euro area } \\
\text { growth rate } \\
1991-2004\end{array}$ & $\begin{array}{l}\text { Euro current } \\
\text { account/GDP } \\
2004\end{array}$ \\
\hline $\begin{array}{l}\text { Mean } \\
\text { (m) }\end{array}$ & $3.06 \%$ p.a. & $-5.7 \%$ & $1.52 \%$ p.a & $2.76 \%$ & $1.82 \%$ p.a & $0.5 \%$ \\
\hline $\begin{array}{l}\text { Standard } \\
\text { deviation } \\
\text { (s) }\end{array}$ & 1.42 & 1.56 & 0.56 & 1.15 & \\
\hline $\begin{array}{l}\text { Risk } \\
\text { adjusted } \\
\text { return z } \\
\text { = m/s }\end{array}$ & 2.15 & & 0.97 & & & \\
\hline $\begin{array}{l}\text { Index of } \\
\text { z }\end{array}$ & 100 & & 45 & & & \\
\hline
\end{tabular}

Sources: Growth rates: Federal Reserve Bank of St. Louis, OECD. The return on capital b $=\mathrm{g} / \mathrm{j}$, where $\mathrm{g}$ is the growth rate and $\mathrm{j}$ is the investment ratio. The latter is relatively similar at 20\% of GDP; Current account/GDP, International Monetary Fund, WEO Sept. 2005, table 1.5 page 20 . 


\subsection{Evaluation of arguments of Optimists and Pessimists}

Since1998 when the current account deficit was $2.4 \%$ of GDP there have been concerns about the effects upon the real value of the US dollar. Subsequently, the ratio of current account deficit/GDP and the core debt/GDP ratio have increased significantly without any downward trend in the real value of the US dollar ${ }^{40}$. The Pessimists base their fears upon an arbitrary number for the debt ratio in equation (1), equal to $\mathrm{A} / \mathrm{g}$ the ratio of the capitalized value of the current account deficit/GDP, where the capitalization factor is the growth rate. They freely admit that they cannot justify what number should set off Warning Signals that the US external net debt is a clear and present danger. They lack a quantitatively useful theoretical framework of analysis.

Moreover, the Pessimists have not refuted the views of the Optimists. The external debt is a menace insofar as there is a significant debt burden. The latter is defined as the ratio of net investment payments/GDP. Net investment payments include interest, dividends, reinvested earnings and compensation of affiliates. Although the core debt/GDP has been growing rapidly, the balance on investment income has not been significantly negative ${ }^{41}$. Figure 1 shows that the debt burden has been a trivial fraction of GDP. It is the distance between the trade balance/GDP (BOPBGSGDP) and current account/GDP (NETFIGDP). Since there has hardly been a debt burden during the period when the core external debt has been rising rapidly, consumption (equation 3.1) will not be significantly adversely affected by the stochastic variables: the return on capital and the effective real rate of interest.

Both the Optimists and the Pessimists must ask why the debt has been rising: is it due to a decline in the saving rate or due to a rise in the productivity of capital? In terms of our analysis, the debt/net worth ratio should be analyzed as follows. The optimal ratio of capital/net worth $k=1+\mathrm{f}$, where $\mathrm{f}$ is the optimal debt ratio. Figure 3 describes the situation. If the debt ratio has been rising to finance consumption or non-productive investment, then the debt ratio has been rising above the optimal line. The debt has been rising without a corresponding increase in net worth $\mathrm{X}=\mathrm{K}$ - L, capital less debt. This would be a movement towards $\mathrm{Q}$ in figure 3. Consumption becomes more vulnerable to

\footnotetext{
${ }^{40}$ See figure 2 for the real exchange rate and current account.

${ }^{41}$ See Federal Reserve Bank of St. Louis, FRED, category "Balance on investment income" BOPBII. The data ultimately derive from US Department of Commerce, Bureau if Economic Analysis.
} 
shocks, as shown in figure 5. If the debt has been rising to finance productive capital formation then debt ratio will not be above the curve.

What are the expected consequences for the real value of the dollar? The Optimists focus upon the capital inflow, equal to investment less saving. It is not convincing to argue that, since investment less saving is positive in the US and negative in the rest of the world, there is an optimal demand for capital inflows and that the current account deficit is not a source of concern. Low saving rates in the US - attributed to the behavior of households and government - relative to those in the creditor countries has led to capital inflows. These inflows have very different effects upon the real exchange rate in the medium and in the long term ${ }^{42}$. In the medium run, the capital inflows appreciate the real exchange rate. However, insofar as the capital inflows are financing consumption - are due to low saving ratios - the debt ratio is rising steadily. In the longer run, the real exchange rate will depreciate to generate a trade balance sufficient to make the interest payments on the growing and high value of the debt. The Optimists neglect to look at the where the debt is heading and the effects upon the long run real value of the dollar.

The scenario that must underlie the Optimists' position is that the return on capital has been higher in the US than in the rest of the world. Then the capital inflow finances capital formation. The real exchange rate appreciates and the debt rises in the medium term. The greater capital increases the productive capacity of the economy, and makes it more competitive. At any real exchange rate, the trade balance rises. As a result in the longer run, the real exchange rate appreciates further and the debt declines. In this case, the rise in current account deficit and hence in the debt in the medium run is not a source of concern.

A crucial question is whether the debt ratio is heading into the region of an excess debt: the region above optimal line in figure 3? The analysis, summarized in BOX 2, explains why the Pessimists' position can be justified on the basis of trends, and not upon current levels, of the debt ratio. Regardless of the stochastic process, the optimal debt ratio should follow the appropriate risk adjusted return. The risk adjusted return $\mathrm{z}$ is a net return divided by the risk, as described in the cases $[\mathrm{A}][\mathrm{B}]$ in BOX 2, depending upon the

\footnotetext{
${ }^{42}$ See the analysis of the fundamental determinants of the real exchange rate in the NATREX model, Stein (2006, chapter 4).
} 
stochastic process. The optimal debt ratio ${ }^{43} \mathrm{f}(\mathrm{z} ; \gamma)=\mathrm{z} /(1-\gamma)$ depends upon both $\mathrm{z}$ and risk aversion $(1-\gamma)$. We have measured the risk adjusted net return $\mathrm{z}$ but one cannot objectively measure $(1-\gamma)>0$ risk aversion. In terms of figure 3 , we know the point on the abscissa $\mathrm{z}$, but we do not know the slope of the line, which is the reciprocal of risk aversion. The lower is the risk aversion, the greater is the slope of the line, and the larger is the optimal debt ratio for any value of $\mathrm{z}$. This is true for all cases in BOX 2.

If the Prototype Model [A] is valid then the optimal debt/net worth ratio $\mathrm{L}_{\mathrm{t}} / \mathrm{X}_{\mathrm{t}}=$ $\mathrm{f}(\mathrm{z} ; \gamma)$ depends upon $\mathrm{z}$ the mean net return / risk. These are presented in the histogram and statistics in figure 6 . The intercept term $f(0)=-0.32$ is not significantly different from zero. The estimate of $f(z ; \gamma)$ is equation (27).

The optimal debt/net worth depends upon the slope of the line in figure 3 , which is $1 /(1-\gamma)$, as well as upon the point on the abscissa (b-r) $/ \sigma^{2}$, the risk adjusted net return.

(27) $\mathrm{f}^{*}=$ optimal debt/net worth = mean NETRETURN1/(1- $\left.\gamma\right)$ variance

$\mathrm{f}^{*}=$ optimal debt/net worth $=0.175 /(1-\gamma)(0.148)^{2}=7.9 /(1-\gamma)$

Graphically, the optimal ratio of debt/net worth in the case above is given by a rectangular hyperbola $f^{*}(1-\gamma)=7.9$. The higher the risk aversion, the lower is the optimal debt/net worth ratio. Any choice of risk aversion is arbitrary, because it is based upon an arbitrary utility function. If risk aversion is unity, then $\mathrm{h}^{*}=$ optimal debt/GDP is equation (28). It is derived from equations (27) and (25). The value of $b$ is the output/GDP ratio which is $b=0.23$.

(28) $\mathrm{h}^{*}=$ optimal debt/GDP $=\mathrm{f} / \mathrm{b}(1+\mathrm{f})=(7.9 / 8.9) /(0.23)=3.8$

In 2004q2 the ratio of net core debt/GDP was 1.32. Hence, the level of the actual debt ratio is not excessive, based upon risk aversion of unity and the Prototype Model. In this case, the position of the Optimists is supported in terms of the level of the debt ratio.

Associated with this estimate of an optimal debt ratio is a ratio of the optimal current account deficit/GDP denoted by A, which is equal to the product of the growth rate and optimal debt ratio. With a growth rate of .04 per annum, the associated optimal current account deficit is $\mathrm{A}=\mathrm{gh}=(0.04)(3.8)=15 \%$ of GDP. The fact that the current

\footnotetext{
${ }^{43}$ The optimal debt/net worth ratio is $f=z /(1-\gamma)+f(0)$. The intercept term $f(0)$ is the optimal debt ratio when the net return $\mathrm{z}=0$. Empirically, $\mathrm{f}(0)$ is very close to zero and is therefore ignored. See Stein (2006, ch. 9) for details.
} 
account deficit in year 2006 is about 6\% is not a cause for alarm, because the debt ratio of 1.32 is less than the estimate 3.8 of the optimal debt/GDP ratio. The greater is risk aversion, the lower is the value of $\mathrm{z} /(1-\gamma)$, and hence the lower is the optimal debt ratio. Because risk aversion is a subjective variable, it is difficult to justify what is the optimal debt ratio. We avoid the insuperable problem of specifying risk aversion $(1-\gamma)$ by assuming that it is constant

If the stochastic process is Ergodic Mean Reversion, case [B] in BOX 2, then the optimal debt/net worth ratio must follow the current return $b_{t}$, not $b$ the mean return in the partial equilibrium analysis. This is also true in the general equilibrium analysis case [C]. Figure 8 graphs NETDEBTGDP the core net debt/GDP and two estimates of $\left(b_{t}-r_{t}\right)$ the net return. In NETRETURN1, the measure of the real interest rate $r=i$, which is just real interest rate. This is relevant when the US debt is denominated in US dollars, and the US bears no exchange risk. The GAINFX1 $=b_{t}-r_{t}$ where $r_{t}=i_{t}+d N_{t} / N_{t}$, is the sum of the real interest rate and the depreciation of the US dollar. This is relevant if the US bears the exchange risk. 
Figure 8. US net debt/GDP, NETRETURN $\left(b_{t}-r_{t}\right)$, GSINFX1 $\left(b_{t}-r_{t}-d_{N} / N_{t}\right)$

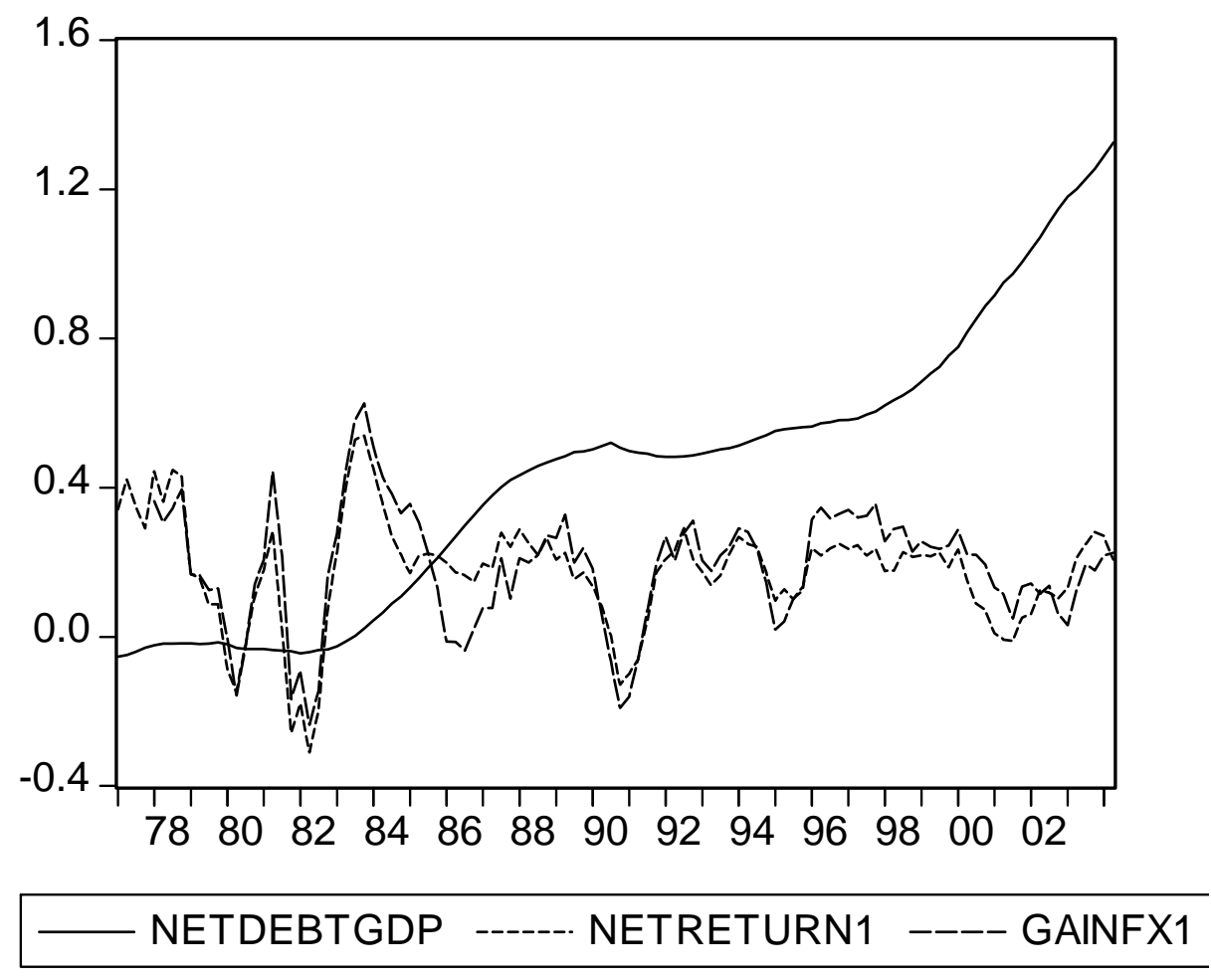

Figure 8 Net return $=\left(b_{t}-r_{t}\right)=$ NETRETURN1; GAINFX1, Core value of the US net debt/GDP $=$ NETDEBTGDP. The NETRETURN1 statistics are in figure 6. Mean core debt ratio $=0.456$, standard deviation $=0.368$.

If risk aversion is relatively constant, then the debt ratio $h_{t}=$ NETDEBTGDP should follow the net return. Figure 8 shows that this is not the case. The debt ratio has been rising significantly since 1982, but neither partial equilibrium measure of the net return has been rising. Regardless of which case is relevant in BOX 2 - partial/ general equilibrium, Prototype Model / Ergodic Mean Reversion Model - the trends of the debt support the Pessimists' position. However, current the level of the debt ratio is not excessive. 


\section{Conclusions}

The "Pessimists" and the "Optimists" disagree whether the United States external deficits and the associated buildup of net foreign liabilities are problems that require urgent attention. Neither side provides a theoretically based empirical measure of what should be an early warning signal (EWS) of impending difficulties. Our contribution is the use of Stochastic Optimal Control/Dynamic Programming (SOC/DP) to derive an inter-temporal optimal debt ratio, and then show how it can be implemented empirically. The optimal debt ratio or debt burden should take into account the vulnerability of consumption to shocks from the productivity of capital, the interest rate and exchange rate. The reason for using SOC/DP is that the shocks are unpredictable, and it is essential to have a feedback control mechanism. The derived optimal ratio depends upon the measurable risk adjusted net return and risk aversion both at home and abroad. An EWS is that the debt ratio deviates significantly from the optimal ratio. On the basis of alternative estimates, we conclude that: (i) The Optimists are correct that the current debt ratio is not a menace, because the current level of the debt ratio is not above the corresponding level of the optimum. (ii) The Pessimists fears are justified on the basis of trends. The trend of the actual debt ratio is higher than that of the optimal ratio. 


\section{REFERENCES}

Bergsten, C. Fred and John Williamson (ed) Dollar Adjustment: How Far? Against What? (2004)? Institute for International Economics, Washington, DC

Bernanke, Ben (2005) The Global Saving Glut and U.S. Current Account Deficit, Homer Jones Lecture, St. Louis, Missouri, <http:///www.federal reserve.gov/boarddocs/speeches/2005>.

Cooper, Richard (2005), Living with Global Imbalances: A Contrarian View, Institute for International Economics, Policy Briefs, PB05-3, Washington, D.C.

Federal Reserve Bank of St. Louis, Economic Data -FRED II data bank $<$ http://research.stlouisfed.org/fred2>

Fleming, Wendell H. and H.M. Soner(2005) Controlled Markov Processes and Viscosity Solutions, Springer, second edition.

Fleming, Wendell H.(2004) Some Optimal Investment, Production and Consumption Models, American Mathematical Society, Contemporary Mathematics 351 Mathematics of Finance, 115-124

(2005) Optimal Investment Models with Minimum Consumption Criteria, Australian Economic Papers, 44 December, 307-21 (2001) "Stochastic Control Models of Optimal Investment and Consumption", Apportiones Matematicas, Modelos Estocasticos II, Sociedad Matematica, Mexico -and Raymond Rishel (1975) Deterministic and Stochastic Optimal Control, Springer-Verlag and Tao Pang, (2004) An Application of Stochastic Control Theory to Financial Economics, SIAM Journal of Control and Optimization, 43 (2) 502-31 
Fleming, Wendell H. and Jerome L. Stein (2004) "Stochastic Optimal Control, International Finance and Debt", Journal of Banking and Finance, 28 (5) May 979-996

International Monetary Fund (2005), World Economic Outlook, Globalization and External Balances, April, Washington, D.C.

-(2005) World Economic Outlook, Building Institutions,

September, Washington, D.C.

Mann, Catherine (1999) Is the US Trade Deficit Sustainable? Institute for International Economics, Washington, DC

Mussa, Michael (2002) Argentina and the Fund: From Triumph to Tragedy, Institute for International Economics, Washington, DC (2004) "Exchange Rate Adjustments Needed to Reduce Global

Payments Imbalances", in Bergsten, C. Fred and John Williamson, op. cit.

Øksendal, Bernt (1995), Stochastic Differential Equations, Springer

Platen, E. (2005) On the Role of the Growth Optimal Portfolio in Finance, Australian Economic Papers, 44 December

Rajan, R. (2006) Financial System Reform and Gobal Current Account Balances, address to American Economic Association, meetings in Boston, MA.

Stein, Jerome L. (2004) "Stochastic Optimal Control Modeling of Debt Crises", American Mathematical Society, Contemporary Mathematics, 351, 979-996

-------------(2005) Optimal Debt and Endogenous Growth in Models of International Finance, Australian Economic Papers, 44 December --(2006), Stochastic Optimal Control, International Finance and Debt Crises, Oxford University Press. 
Truman, Edwin (2005), Postponing Global Adjustment, Institute for International Economics, Policy Briefs, PB05-6 Washington, D.C.

Williamson, John (2004) Overview: Designing a Dollar Policy in Bergsten, C. Fred and John Williamson (ed) Dollar Adjustment: How Far? Against What? (2004)? Institute for International Economics, Washington, DC 


\section{CESifo Working Paper Series}

(for full list see www.cesifo-group.de)

1740 Ben J. Heijdra and Ward E. Romp, Ageing and Growth in the Small Open Economy, June 2006

1741 Robert Fenge and Volker Meier, Subsidies for Wages and Infrastructure: How to Restrain Undesired Immigration, June 2006

1742 Robert S. Chirinko and Debdulal Mallick, The Elasticity of Derived Demand, Factor Substitution and Product Demand: Corrections to Hicks' Formula and Marshall's Four Rules, June 2006

1743 Harry P. Bowen, Haris Munandar and Jean-Marie Viaene, Evidence and Implications of Zipf's Law for Integrated Economies, June 2006

1744 Markku Lanne and Helmut Luetkepohl, Identifying Monetary Policy Shocks via Changes in Volatility, June 2006

1745 Timo Trimborn, Karl-Josef Koch and Thomas M. Steger, Multi-Dimensional Transitional Dynamics: A Simple Numberical Procedure, June 2006

1746 Vivek H. Dehejia and Yiagadeesen Samy, Labor Standards and Economic Integration in the European Union: An Empirical Analysis, June 2006

1747 Carlo Altavilla and Paul De Grauwe, Forecasting and Combining Competing Models of Exchange Rate Determination, June 2006

1748 Olaf Posch and Klaus Waelde, Natural Volatility, Welfare and Taxation, June 2006

1749 Christian Holzner, Volker Meier and Martin Werding, Workfare, Monitoring, and Efficiency Wages, June 2006

1750 Steven Brakman, Harry Garretsen and Charles van Marrewijk, Agglomeration and Aid, June 2006

1751 Robert Fenge and Jakob von Weizsäcker, Mixing Bismarck and Child Pension Systems: An Optimum Taxation Approach, June 2006

1752 Helge Berger and Michael Neugart, Labor Courts, Nomination Bias, and Unemployment in Germany, June 2006

1753 Chris van Klaveren, Bernard van Praag and Henriette Maassen van den Brink, A Collective Household Model of Time Allocation - a Comparison of Native Dutch and Immigrant Households in the Netherlands, June 2006

1754 Marko Koethenbuerger, Ex-Post Redistribution in a Federation: Implications for Corrective Policy, July 2006 
1755 Axel Dreher, Jan-Egbert Sturm and Heinrich Ursprung, The Impact of Globalization on the Composition of Government Expenditures: Evidence from Panel Data, July 2006

1756 Richard Schmidtke, Private Provision of a Complementary Public Good, July 2006

1757 J. Atsu Amegashie, Intentions and Social Interactions, July 2006

1758 Alessandro Balestrino, Tax Avoidance, Endogenous Social Norms, and the Comparison Income Effect, July 2006

1759 Øystein Thøgersen, Intergenerational Risk Sharing by Means of Pay-as-you-go Programs - an Investigation of Alternative Mechanisms, July 2006

1760 Pascalis Raimondos-Møller and Alan D. Woodland, Steepest Ascent Tariff Reforms, July 2006

1761 Ronald MacDonald and Cezary Wojcik, Catching-up, Inflation Differentials and Credit Booms in a Heterogeneous Monetary Union: Some Implications for EMU and new EU Member States, July 2006

1762 Robert Dur, Status-Seeking in Criminal Subcultures and the Double Dividend of ZeroTolerance, July 2006

1763 Christa Hainz, Business Groups in Emerging Markets - Financial Control and Sequential Investment, July 2006

1764 Didier Laussel and Raymond Riezman, Fixed Transport Costs and International Trade, July 2006

1765 Rafael Lalive, How do Extended Benefits Affect Unemployment Duration? A Regression Discontinuity Approach, July 2006

1766 Eric Hillebrand, Gunther Schnabl and Yasemin Ulu, Japanese Foreign Exchange Intervention and the Yen/Dollar Exchange Rate: A Simultaneous Equations Approach Using Realized Volatility, July 2006

1767 Carsten Hefeker, EMU Enlargement, Policy Uncertainty and Economic Reforms, July 2006

1768 Giovanni Facchini and Anna Maria Mayda, Individual Attitudes towards Immigrants: Welfare-State Determinants across Countries, July 2006

1769 Maarten Bosker and Harry Garretsen, Geography Rules Too! Economic Development and the Geography of Institutions, July 2006

1770 M. Hashem Pesaran and Allan Timmermann, Testing Dependence among Serially Correlated Multi-category Variables, July 2006

1771 Juergen von Hagen and Haiping Zhang, Financial Liberalization in a Small Open Economy, August 2006 
1772 Alessandro Cigno, Is there a Social Security Tax Wedge?, August 2006

1773 Peter Egger, Simon Loretz, Michael Pfaffermayr and Hannes Winner, Corporate Taxation and Multinational Activity, August 2006

1774 Jeremy S.S. Edwards, Wolfgang Eggert and Alfons J. Weichenrieder, The Measurement of Firm Ownership and its Effect on Managerial Pay, August 2006

1775 Scott Alan Carson and Thomas N. Maloney, Living Standards in Black and White: Evidence from the Heights of Ohio Prison Inmates, 1829 - 1913, August 2006

1776 Richard Schmidtke, Two-Sided Markets with Pecuniary and Participation Externalities, August 2006

1777 Ben J. Heijdra and Jenny E. Ligthart, The Transitional Dynamics of Fiscal Policy in Small Open Economies, August 2006

1778 Jay Pil Choi, How Reasonable is the 'Reasonable' Royalty Rate? Damage Rules and Probabilistic Intellectual Property Rights, August 2006

1779 Ludger Woessmann, Efficiency and Equity of European Education and Training Policies, August 2006

1780 Gregory Ponthiere, Growth, Longevity and Public Policy, August 2006

1781 Laszlo Goerke, Corporate and Personal Income Tax Declarations, August 2006

1782 Florian Englmaier, Pablo Guillén, Loreto Llorente, Sander Onderstal and Rupert Sausgruber, The Chopstick Auction: A Study of the Exposure Problem in Multi-Unit Auctions, August 2006

1783 Adam S. Posen and Daniel Popov Gould, Has EMU had any Impact on the Degree of Wage Restraint?, August 2006

1784 Paolo M. Panteghini, A Simple Explanation for the Unfavorable Tax Treatment of Investment Costs, August 2006

1785 Alan J. Auerbach, Why have Corporate Tax Revenues Declined? Another Look, August 2006

1786 Hideshi Itoh and Hodaka Morita, Formal Contracts, Relational Contracts, and the Holdup Problem, August 2006

1787 Rafael Lalive and Alejandra Cattaneo, Social Interactions and Schooling Decisions, August 2006

1788 George Kapetanios, M. Hashem Pesaran and Takashi Yamagata, Panels with Nonstationary Multifactor Error Structures, August 2006

1789 Torben M. Andersen, Increasing Longevity and Social Security Reforms, August 2006 
1790 John Whalley, Recent Regional Agreements: Why so many, why so much Variance in Form, why Coming so fast, and where are they Headed?, August 2006

1791 Sebastian G. Kessing and Kai A. Konrad, Time Consistency and Bureaucratic Budget Competition, August 2006

1792 Bertil Holmlund, Qian Liu and Oskar Nordström Skans, Mind the Gap? Estimating the Effects of Postponing Higher Education, August 2006

1793 Peter Birch Sørensen, Can Capital Income Taxes Survive? And Should They?, August 2006

1794 Michael Kosfeld, Akira Okada and Arno Riedl, Institution Formation in Public Goods Games, September 2006

1795 Marcel Gérard, Reforming the Taxation of Multijurisdictional Enterprises in Europe, a Tentative Appraisal, September 2006

1796 Louis Eeckhoudt, Béatrice Rey and Harris Schlesinger, A Good Sign for Multivariate Risk Taking, September 2006

1797 Dominique M. Gross and Nicolas Schmitt, Why do Low- and High-Skill Workers Migrate? Flow Evidence from France, September 2006

1798 Dan Bernhardt, Stefan Krasa and Mattias Polborn, Political Polarization and the Electoral Effects of Media Bias, September 2006

1799 Pierre Pestieau and Motohiro Sato, Estate Taxation with Both Accidental and Planned Bequests, September 2006

1800 Øystein Foros and Hans Jarle Kind, Do Slotting Allowances Harm Retail Competition?, September 2006

1801 Tobias Lindhe and Jan Södersten, The Equity Trap, the Cost of Capital and the Firm's Growth Path, September 2006

1802 Wolfgang Buchholz, Richard Cornes and Wolfgang Peters, Existence, Uniqueness and Some Comparative Statics for Ratio- and Lindahl Equilibria: New Wine in Old Bottles, September 2006

1803 Jan Schnellenbach, Lars P. Feld and Christoph Schaltegger, The Impact of Referendums on the Centralisation of Public Goods Provision: A Political Economy Approach, September 2006

1804 David-Jan Jansen and Jakob de Haan, Does ECB Communication Help in Predicting its Interest Rate Decisions?, September 2006

1805 Jerome L. Stein, United States Current Account Deficits: A Stochastic Optimal Control Analysis, September 2006 